Water-Resources Investigation Report 99-4235

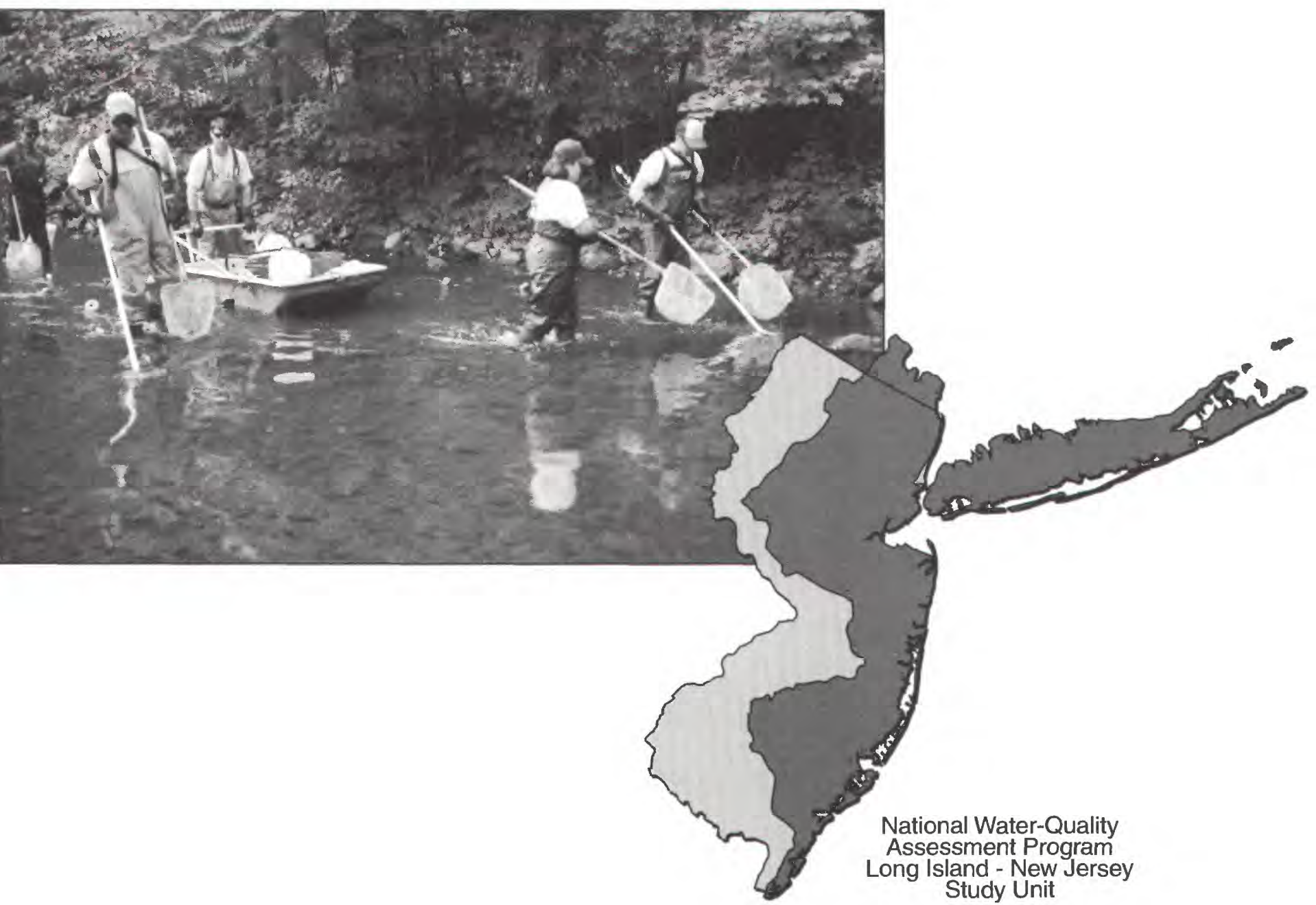

National Water-Quality Assessment Program 


\section{TRACE ELEMENTS AND ORGANOCHLORINE COMPOUNDS IN BED SEDIMENT AND FISH TISSUE AT SELECTED SITES IN NEW JERSEY STREAMS--SOURCES AND EFFECTS}

By Gary R. Long, Ming Chang, and Jonathan G. Kennen

U.S. GEOLOGICAL SURVEY

Water-Resources Investigations Report 99-4235

National Water-Quality Assessment Program

West Trenton, New Jersey 2000

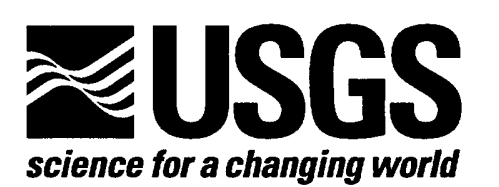




\section{U.S. DEPARTMENT OF THE INTERIOR \\ BRUCE BABBIT, Secretary}

\section{U.S. GEOLOGICAL SURVEY}

Charles G. Groat, Director

For additional information write to:

District Chief

U.S Geological Survey Mountain View Office Park

810 Bear Tavern Road, Suite 206

West Trenton, NJ 08628
Copies of this report can be purchased from:

U.S. Geological Survey

Branch of Information Services Box 25286

Denver, CO 80225-0286 


\section{CONTENTS}

Page

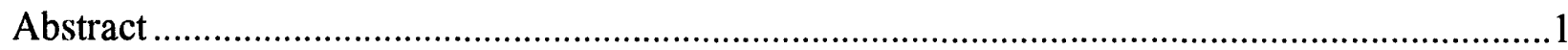

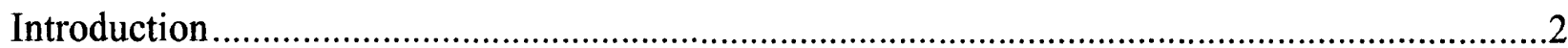

Description of study area ............................................................................. 2

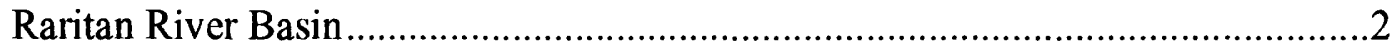

Passaic River Basin ............................................................................... 4

Rahway River Basin ......................................................................

Great Egg Harbor River Basin .................................................................5

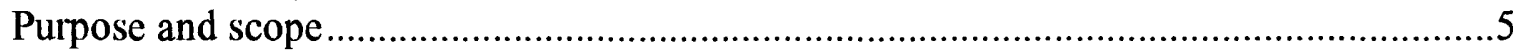

Trace elements and organochlorine compounds in aquatic environments........................5

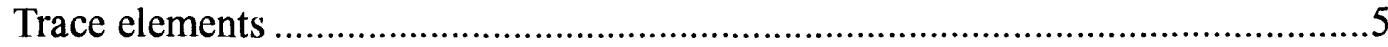

Organochlorine compounds ......................................................................6

Acknowledgments............................................................................................. 7

Methods of sample collection and analysis .....................................................................

Sample collection and processing ...................................................................

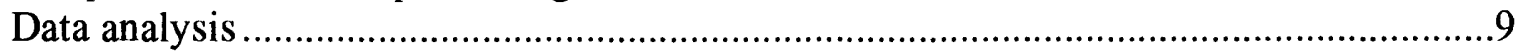

Linear regression analyses of selected basin characteristics............................

Estimation of baseline trace-element concentrations.......................................10

Calculation of trace-element loading from point sources .............................. 11

Calculation of organochlorine compounds .............................................. 11

Occurrence of trace elements and organochlorine compounds ...........................................12

Trace elements in bed sediment and fish tissue .................................................... 12

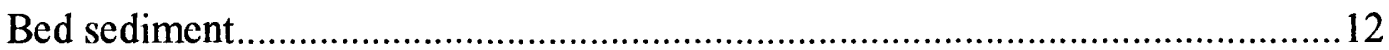

Fish tissue ........................................................................................ 15

Organochlorine compounds in bed sediment and fish tissue .................................... 17

Bed sediment.................................................................................. 17

Fish tissue ....................................................................................... 17

Assessment of trace elements and organochlorine compounds ........................................17

Trace elements in bed sediment and fish tissue ......................................................17

Bed sediment................................................................................. 17

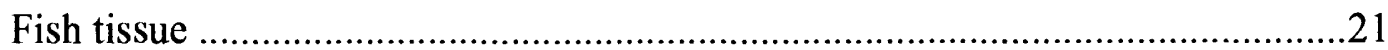

Organochlorine compounds in bed sediment and fish tissue .......................................22

Importance of sampling multiple media ..............................................................23

Potential for adverse biological effects ................................................................23

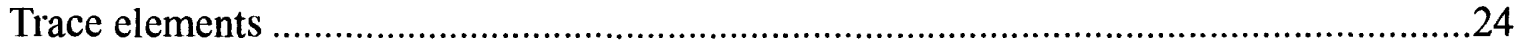

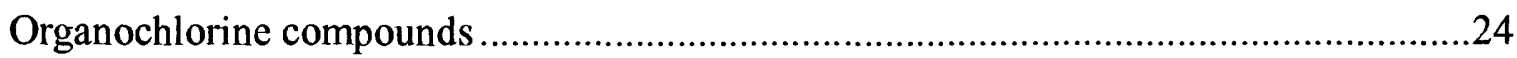

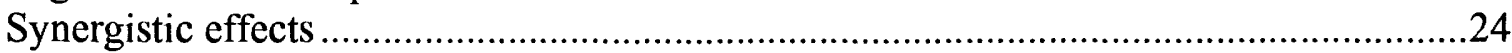

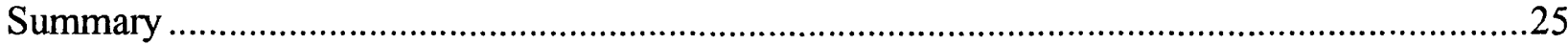

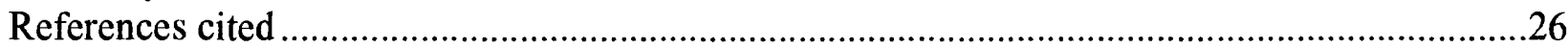




\section{ILLUSTRATIONS}

Page

Figure 1. Map showing location of sites sampled for bed sediment and fish tissue and physiographic provinces in New Jersey....

2. Graph showing normal probability distribution of copper from 192 bed-sediment samples collected at sites throughout the New Jersey Coastal Plain

3. Graph showing concentrations of selected trace elements in bed sediment, estimated baseline concentrations, sediment-quality guidelines, and median concentrations

\section{TABLES}

Table 1. Land use characteristics for selected LINJ study-unit sites 4

2. Method reporting limits for selected trace elements determined in bed sediment and fish livers

3. Characteristics of fish-tissue and bed-sediment samples collected at selected LINJ study-unit sites. 8

4. Estimated baseline concentrations of selected trace elements in bed sediment and soil from New Jersey Coastal Plain and non-Coastal Plain sites

5. Method reporting limits for organochlorine compounds in bed sediment and whole-body-fish tissue

6. Linear relation probabilities between trace-element concentrations in bed sediment to land use and population density at selected LINJ study-unit sites

7. Concentrations of selected trace elements in fish livers at selected LINJ studyunit sites

8. Concentrations of organochlorine compounds in bed-sediment samples collected at selected LINJ study-unit sites

9. Linear relation probabilities of organochlorine compounds in fish tissue and bed sediment to basin characteristics at selected LINJ study-unit sites .

10. Concentrations of organochlorine compounds in whole-body-fish tissue samples collected at selected LINJ study-unit sites 


\section{CONVERSION FACTORS}

$\begin{array}{lcl}\text { Multiply } & \text { By } & \text { To obtain } \\ \text { inch (in.) } & 2.54 & \text { centimeter } \\ \text { inch (in.) } & 25.4 & \text { millimeter } \\ \text { inch (in.) } & 25,400 & \text { micrometer } \\ \text { square mile ( } \mathrm{mi}^{2} \text { ) } & 2.590 & \text { square kilometer } \\ \text { ounce, avoirdupois (oz) } & 28.35 & \text { gram } \\ \text { pound, avoirdupois (lb) } & 0.4536 & \text { kilogram }\end{array}$

degree Fahrenheit $\left({ }^{\circ} \mathrm{F}\right)^{\circ} \mathrm{C}=5 / 9 \times\left({ }^{\circ} \mathrm{F}-32\right)$ degree Celsius $\left({ }^{\circ} \mathrm{C}\right)$

Temperature given in degrees Fahrenheit $\left({ }^{\circ} \mathrm{F}\right)$ and Celsius $\left({ }^{\circ} \mathrm{C}\right)$ may be converted to degrees Celsius $\left({ }^{\circ} \mathrm{C}\right)$ and Kelvin $\left({ }^{\circ} \mathrm{K}\right)$ by the following equations:

Concentrations of substances in bed sediment and fish are given in weight percent, $\mu \mathrm{g} / \mathrm{g}$ (micrograms per gram), or $\mu \mathrm{g} / \mathrm{kg}$ (micrograms per kilogram). $\mu \mathrm{g} / \mathrm{g}$ is equivalent to $\mathrm{ppm}$ (parts per million) and $\mu \mathrm{g} / \mathrm{kg}$ is equivalent to parts per billion ( $\mathrm{ppb}$ ).

\section{Water-quality abbreviations}

$\mathrm{mL}$ - milliliter

Use of trade, product, or firm names in this report is for identification purposes only and does not constitute endorsement by the U.S. Geological Survey. 


\section{FOREWORD}

The mission of the U.S. Geological Survey (USGS) is to assess the quantity and quality of the earth resources of the Nation and to provide information that will assist resource managers and policymakers at Federal, State, and local levels in making sound decisions. Assessment of water-quality conditions and trends is an important part of this overall mission.

One of the greatest challenges faced by waterresources scientists is acquiring reliable information that will guide the use and protection of the Nation's water resources. That challenge is being addressed by Federal, State, interstate, and local water-resource agencies and by many academic institutions. These organizations are collecting water-quality data for a host of purposes that include: compliance with permits and water-supply standards; development of remediation plans for specific contamination problems; operational decisions on industrial, wastewater, or water-supply facilities; and research on factors that affect water quality. An additional need for waterquality information is to provide a basis on which regional- and national-level policy decisions can be based. Wise decisions must be based on sound information. As a society we need to know whether certain types of water-quality problems are isolated or ubiquitous, whether there are significant differences in conditions among regions, whether the conditions are changing over time, and why these conditions change from place to place and over time. The information can be used to help determine the efficacy of existing water-quality policies and to help analysts determine the need for and likely consequences of new policies.

To address these needs, the U.S. Congress appropriated funds in 1986 for the USGS to begin a pilot program in seven project areas to develop and refine the National Water-Quality Assessment (NAWQA) Program. In 1991, the USGS began full implementation of the program. The NAWQA Program builds upon an existing base of water-quality studies of the USGS, as well as those of other Federal, State, and local agencies. The objectives of the NAWQA Program are to:

- Describe current water-quality conditions for a large part of the Nation's freshwater streams, rivers, and aquifers. time.

- Describe how water quality is changing over
- Improve understanding of the primary natural and human factors that affect water-quality conditions.

This information will help support the development and evaluation of management, regulatory, and monitoring decisions by other Federal, State, and local agencies to protect, use, and enhance water resources.

The goals of the NAWQA Program are being achieved through ongoing and proposed investigations of 59 of the Nation's most important river basins and aquifer systems, which are referred to as study units. These study units are distributed throughout the Nation and cover a diversity of hydrogeologic settings. More than two-thirds of the Nation's freshwater use occurs within the 59 study units and more than two-thirds of the people served by public watersupply systems live within their boundaries.

National synthesis of data analysis, based on aggregation of comparable information obtained from the study units, is a major component of the program. This effort focuses on selected water-quality topics using nationally consistent information. Comparative studies will explain differences and similarities in observed water-quality conditions among study areas and will identify changes and trends and their causes. The first topics addressed by the national synthesis are pesticides, nutrients, volatile organic compounds, and aquatic biology. Discussions on these and other waterquality topics will be published in periodic summaries of the quality of the Nation's ground and surface water as the information becomes available.

This report is an element of the comprehensive body of information developed as part of the NAWQA Program. The program depends heavily on the advice, cooperation, and information from many Federal, State, interstate, Tribal, and local agencies and the public. The assistance and suggestions of all are greatly appreciated.

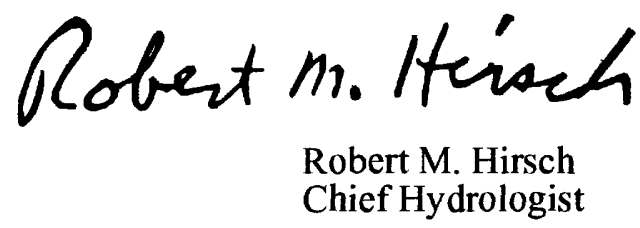




\title{
TRACE ELEMENTS AND ORGANOCHLORINE COMPOUNDS IN BED SEDIMENT AND FISH TISSUE AT SELECTED SITES IN NEW JERSEY STREAMS -- SOURCES AND EFFECTS
}

\author{
By Gary R. Long, Ming Chang, and Jonathan G. Kennen
}

\section{ABSTRACT}

Bed-sediment and fish-tissue samples were collected for the Long Island-New Jersey National Water-Quality Assessment (LINJNAWQA) program in fall 1997 and analyzed to determine the concentrations of trace elements and organochlorines. Bed-sediment samples, fish-tissue samples, or both were collected from 10 sites in New Jersey with various land uses. Antimony ( $\mathrm{Sb}$ ), arsenic (As), cadmium $(\mathrm{Cd})$, copper $(\mathrm{Cu})$, chromium $(\mathrm{Cr})$, lead $(\mathrm{Pb})$, manganese $(\mathrm{Mn})$, mercury $(\mathrm{Hg})$, nickel $(\mathrm{Ni})$, selenium ( $\mathrm{Se})$, zinc $(\mathrm{Zn})$, dichlorodiphenyltrichloroethane (DDT), polychlorinated biphenyls (PCBs), and chlordane were selected for detailed analyses. Results were compared to land-use characteristics and population density by using regression analyses. Sediment-quality guidelines (threshold effect level, TEL, and probable effect level, PEL) established by the Canadian Council of Ministers of the Environment and tissue-residue guidelines developed by the U.S. Environmental Protection Agency were used to assess relative toxicity.

All selected trace elements were detected in bed-sediment samples from seven of the eight sites sampled; $\mathrm{Sb}, \mathrm{As}, \mathrm{Cd}, \mathrm{Hg}$, and $\mathrm{Se}$ were not analyzed for in samples from one site. The strongest relations were between population density and concentrations in bed sediment for all selected trace elements except $\mathrm{Cr}, \mathrm{Mn}$, and Se. Significant positive relations $(p<0.05)$ were identified between total urban land use and concentrations in bed sediment for all selected trace elements except $\mathrm{Cr}, \mathrm{Hg}$, and $\mathrm{Ni}$. Urban industrial/commercial land use was significantly related $(p<0.05)$ to concentrations in bed sediment of $\mathrm{Sb}, \mathrm{Cd}, \mathrm{Cu}, \mathrm{Ni}$, and $\mathrm{Zn}$. Of the trace elements analyzed for $(\mathrm{As}, \mathrm{Cd}, \mathrm{Cr}, \mathrm{Cu}$, $\mathrm{Pb}, \mathrm{Hg}$, and $\mathrm{Zn}$ ), Cu was the only one significantly related to annual trace-element loading from point sources.

All sites were found to have the potential for adverse biological effects that are associated with concentrations of at least two trace elements in bed sediment. The Rahway River near Springfield had the greatest potential for adverse biological effects; concentrations of all trace elements at this site exceeded TELs, and with the exception of $\mathrm{As}, \mathrm{Cd}$, and $\mathrm{Cu}$, exceeded PELs.

$\mathrm{Cu}, \mathrm{Mn}, \mathrm{Hg}$, and Se were detected in fish livers at all sites. No significant relations $(p>0.05)$ were found between trace-element concentrations in fish tissue and those in bed sediment or between fish tissue and land-use category or population density.

Total chlordane was detected in bedsediment samples from five sites and in wholefish samples from seven sites. DDT and PCBs were detected at all sites in whole-fish and bedsediment samples at seven and four sites, respectively. Significant positive relations $(p<0.05)$ were found between DDT and chlordane concentrations in bed sediment and population density. No significant relations 
were identified between organochlorine concentrations in fish tissue and bed sediment or between those in fish tissue and land use. One-half of all bed-sediment samples contained concentrations of chlordane, DDT, and PCBs that exceeded TELs. Concentrations of chlordane and PCBs in fish-tissue samples from many sites exceeded established guidelines for fish-eating wildlife.

\section{INTRODUCTION}

In 1991, the U.S. Geological Survey (USGS) began full implementation of the National Water Quality Assessment (NAWQA) program. The goals of the NAWQA program are to describe the status of the Nation's surface- and ground-water resources, assess current water-quality trends, and identify the factors affecting water quality with an emphasis on a regional scale. Water quality typically is assessed based on an approach that integrates biological and surface- and groundwater information. The assessment of water quality is carried out through investigations of the 59 most important river basins and aquifer systems in the Nation, which are referred to as study units. One component of the NAWQA program is the investigation of the occurrence and distribution of contaminants, namely trace elements and organochlorines, in biological tissues (Crawford and Luoma, 1993). This study in the Long Island-New Jersey (LINJ) study unit was conducted to determine the presence of trace elements and organochlorines in fish tissue and bed sediment.

\section{Description of Study Area}

Assessment activities began in the LINJ study unit in 1994. This study unit encompasses about $6,000 \mathrm{mi}^{2}$, including all of Long Island, N.Y., most of the Atlantic Coastal Basins, and the Passaic, Raritan, and Hackensack River Basins in New Jersey (fig. 1). Popu- lation in the LINJ study unit is about 12.5 million, with the highest density in western Long Island and northeastern New Jersey. Urban-residential, urban-industrial/commercial and agricultural are the dominant land uses in the LINJ study unit. The sites assessed in the study are located in the Raritan, Passaic, Rahway, and Great Egg Harbor River Basins. These four basins differ in geologic characteristics, size, land use, and population density.

\section{Raritan River Basin}

The Raritan River Basin $\left(1,100 \mathrm{mi}^{2}\right)$ is the largest river basin located entirely in New Jersey and extends across the New England, Piedmont, and Coastal Plain physiographic provinces (fig. 1). Four of the study sites are located within the Raritan River Basin--Stony Brook at Princeton, Neshanic River at Reaville, Bound Brook at Middlesex, and Raritan River at Queens Bridge.

The Stony Brook at Princeton site is on a fourth order stream that drains formerly agricultural and forested lands which are rapidly being converted into residential areas. Land use in this basin is mostly forested, and it is one of the least densely populated basins in the study area (320 people/mi ${ }^{2}$; table 1$)$. The Neshanic River at Reaville site is on a fourth order stream that drains a predominantly agricultural basin; the remainder of the basin is composed of forested, urban-residential, and urban industrial/commercial land uses. Population density in the drainage basin $\left(331\right.$ people $\left./ \mathrm{mi}^{2}\right)$ is similar to that of Stony Brook (fig. 1; table 1). The Bound Brook at Middlesex site is on a third order stream that drains a basin with one of the highest percentages of urban industrial/ commercial land use and population density in the study area (24 percent; 3,324 people $/ \mathrm{mi}^{2}$ ). Urban-residential and forested are the other land uses in this basin. The Raritan River at Queens Bridge site is one of two LINJ study unit integrator sites, which are sites located on a mainstem river in a drainage basin with mixed 


\section{EXPLANATION}

Drainage basin boundary

\section{Fish Tissue}

01379000 Passaic River at Millington

01394200 Rahway River at Washington Park

Bed sediment sampling sites

01382000 Passaic River at Two Bridges

01394500 Rahway River at Springfield

Fish tissue and bed sediment sampling sites

01390500 Saddle River at Ridgewood

01398000 Neshanic River at Reaville

01401000 Stony Brook at Princeton

01403300 Raritan River at Queens Bridge

01403900 Bound Brook at Middlesex

01410784 Great Egg Harbor River at Sicklerville
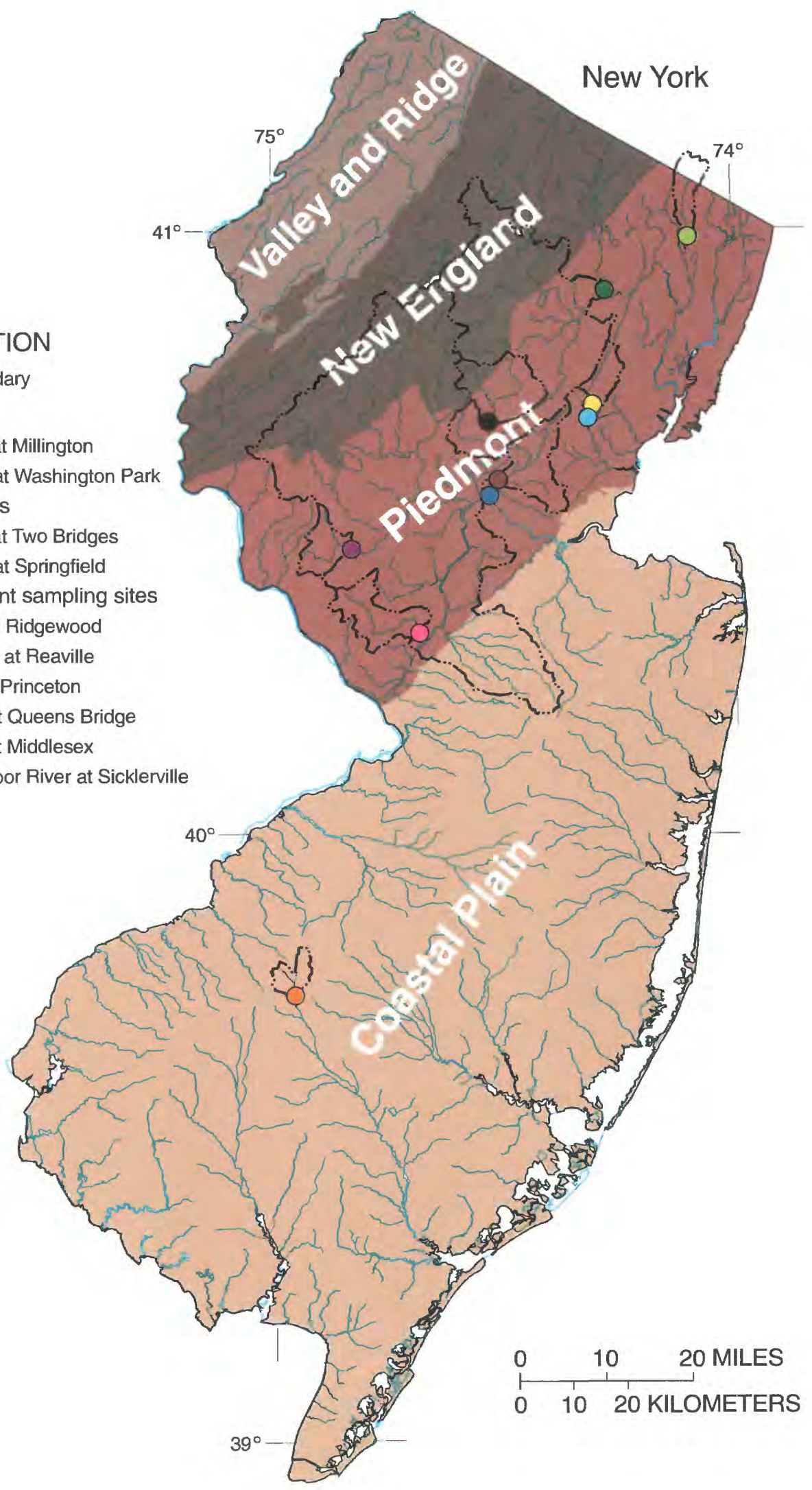

Figure 1. Location of sites sampled for bed sediment and fish tissue and physiographic provinces in New Jersey. 


\section{Table 1. Land-use characteristics for selected Long Island-New Jersey study-unit sites}

[Land use is reported in percent of total drainage area (New Jersey Department of Environmental Protection, 1996); people/ $\mathrm{mi}^{2}$, people per square mile. Percentages do not total 100 percent because of rounding.]

\begin{tabular}{|c|c|c|c|c|c|c|c|c|}
\hline \multirow[b]{3}{*}{ Site name } & \multirow[b]{3}{*}{$\begin{array}{c}\text { Site } \\
\text { identifier }\end{array}$} & \multirow{3}{*}{$\begin{array}{c}\text { Drainage } \\
\text { area } \\
\left(\mathrm{mi}^{2}\right)\end{array}$} & \multicolumn{5}{|c|}{ Land use } & \multirow{3}{*}{$\begin{array}{c}\text { Population } \\
\text { density } \\
\text { (people/ } \\
\mathrm{mi}^{2} \text { ) }\end{array}$} \\
\hline & & & \multicolumn{2}{|c|}{ Total urban } & \multirow[b]{2}{*}{ Agricultural } & \multirow[b]{2}{*}{ Forested } & \multirow{2}{*}{$\begin{array}{l}\text { Water, } \\
\text { wetland, } \\
\text { and barren } \\
\text { land }\end{array}$} & \\
\hline & & & $\begin{array}{l}\text { Industrial/ } \\
\text { commercial }\end{array}$ & Residential & & & & \\
\hline $\begin{array}{l}\text { Passaic River near } \\
\text { Millington }\end{array}$ & 01379000 & 55.4 & 8 & 30 & 10 & 29 & 21 & 603 \\
\hline Passaic River at Two Bridges & 01382000 & 361 & 15 & 32 & 3 & 35 & 9 & 1,152 \\
\hline Saddle River at Ridgewood & 01390500 & 21.6 & 11 & 75 & 2 & 11 & 0 & 1,783 \\
\hline $\begin{array}{l}\text { Rahway River at Washington } \\
\text { Park }\end{array}$ & 01394200 & 18.1 & 23 & 55 & 0 & 21 & 0 & 4,034 \\
\hline $\begin{array}{l}\text { Rahway River near } \\
\text { Springfield }\end{array}$ & 01394500 & 25.0 & 24 & 55 & 0 & 18 & 1 & 4,034 \\
\hline Neshanic River at Reaville & 01398000 & 25.7 & 4 & 15 & 53 & 27 & 1 & 331 \\
\hline Stony Brook at Princeton & 01401000 & 44.5 & 5 & 18 & 28 & 47 & 1 & 320 \\
\hline $\begin{array}{l}\text { Raritan River at Queens } \\
\text { Bridge }\end{array}$ & 01403300 & 804 & 6 & 19 & 30 & 35 & 6 & 525 \\
\hline Bound Brook at Middlesex & 01403900 & 48.4 & 24 & 44 & 1 & 25 & 4 & 3,324 \\
\hline $\begin{array}{l}\text { Great Egg Harbor River at } \\
\text { Sicklerville }\end{array}$ & 01410784 & 15.1 & 8 & 24 & 10 & 43 & 13 & 957 \\
\hline
\end{tabular}

land use--forested, agricultural, urban-residential and urban industrial/commercial.

\section{Passaic River Basin}

The Passaic River Basin is the third largest basin in New Jersey and is considered to have a high percentage of urban land use (New Jersey Department of Environmental Protection, 1995). The Passaic River drains basins in the Piedmont and New England physiographic provinces. Three sites--Saddle River at Ridgewood, Passaic River at Millington, and Passaic River at Two Bridges--lie within this basin (fig. 1). The Saddle River at Ridgewood site is on a third order stream; urban-residential is the dominant land use (75 percent; table 1). The Passaic River at Millington site is on a fourth order stream that drains a basin $\left(55.4 \mathrm{mi}^{2}\right)$ with almost equal amounts of urban-residential and forested land uses and lesser amounts of wetland and agricultural land uses. The Passaic River at Two Bridges site, the second LINJ integrator site, is on a sixth order stream and drains a basin $\left(361 \mathrm{mi}^{2}\right)$ composed of forested, urban-residential, and urban industrial/ commercial land uses.

\section{Rahway River Basin}

The Rahway River near Springfield site is on a third order stream that drains the most densely populated $\left(4,034\right.$ people $\left./ \mathrm{mi}^{2}\right)$ basin $\left(25.0 \mathrm{mi}^{2}\right)$ in this study area. The Rahway River at Washington Park site is located upstream from Rahway River near Springfield; this stream drains an area of $18.1 \mathrm{mi}^{2}$. Land use in both drainage areas is predominantly urban- 
residential and urban industrial/commercial (fig. 1; table 1).

\section{Great Egg Harbor River Basin}

The Great Egg Harbor River at Sicklerville site is on a third order stream and is the only site in the study area that is located in the New Jersey Coastal Plain. Although the basin comprises mostly forested land, many of the agricultural areas are changing to residential land use (table 1).

\section{Purpose and Scope}

This report describes (1) the presence of selected trace elements and organochlorine compounds, specifically three classes of organochlorines--chlordane, dichlorodiphenyltrichloroethane (DDT), and polychlorinated biphenyls (PCBs)--in samples of fish tissue and bed sediment from selected sites in the LINJ study unit and (2) the relations of trace-element concentrations and organochlorine concentrations in bed sediment and fish tissue to land use, population density, and point sources. Bedsediment and fish-tissue samples were collected at 10 sites in New Jersey in fall 1997. Trace-element and organochlorine data were analyzed by using graphical and statistical methods, and results are shown in graphs and tables.

\section{Trace Elements and Organochlorine Compounds in Aquatic Environments}

\section{Trace Elements}

Geologic weathering accounts for the natural release of trace elements into the aquatic environment. Human activities accelerate this accumulation through point and nonpoint source contamination. Major point sources of trace elements are industrial and domestic wastewater discharges. A wide variety of industries, including paper manufac- turing, chemical manufacturing, steel production, fertilizer production, and petroleum refining, use trace elements in their various processes. Consequently, trace-elementenriched effluent either can be discharged by such industries directly to receiving waters or can be diverted to wastewater-treatment facilities (Forstner and Wittman, 1983). Domestic effluent from wastewater-treatment facilities has been identified as a significant source of trace elements to aquatic systems (Forstner and Wittman, 1983).

Many non-point sources contribute to the accumulation of trace elements in the aquatic environment. The combustion of fossil fuels emits trace elements, particularly $\mathrm{As}, \mathrm{Cd}, \mathrm{Cr}$, $\mathrm{Hg}$, and $\mathrm{Pb}$ (names and symbols of elements are listed in table 2), into the atmosphere where they are subsequently deposited either directly into waterways or indirectly onto watersheds where they can be mobilized into aquatic systems through stormwater runoff (Fornster and Wittman, 1983; Harte and others, 1991; O'Brien, 1997). Emissions from industrial processes also contribute trace elements to aquatic systems. Activities, such as plating, smelting, refining, and other metal processing, release trace elements, including $\mathrm{Sb}, \mathrm{Cd}, \mathrm{Cr}$, $\mathrm{Cu}, \mathrm{Pb}, \mathrm{Mn}, \mathrm{Hg}, \mathrm{Ni}$, and $\mathrm{Zn}$ into the atmosphere; they can then be deposited onto watersheds (Harte and others, 1991; Winter, 1998; O'Brien, 1997; Brigham and others, 1997). Automobile exhaust is an additional source of trace elements to the atmosphere (Ondov and others, 1982). Applications of fertilizers and pesticides can contribute $\mathrm{As}, \mathrm{Cd}$, and $\mathrm{Hg}$ to aquatic systems through volatilization, runoff, soil leaching, and drift from aerial spraying (Harte and others, 1991; Nriagu and Pacyna, 1988; Winter, 1998; Nadakavukaren, 1995). Leachate from landfills and solid-waste dumps constitutes an additional non-point source of trace elements (Forstner and Wittman, 1983; O'Brien, 1997). 
Table 2. Method reporting limits for selected trace elements determined in bed sediment and fish livers

[Units are reported in micrograms per gram, dry weight]

\begin{tabular}{lccc}
\hline & & \multicolumn{2}{c}{ Method reporting limit } \\
\cline { 3 - 4 } Trace element & Symbol & $\begin{array}{c}\text { Bed } \\
\text { sediment }\end{array}$ & Fish tissue \\
\hline Antimony & $\mathrm{Sb}$ & 0.1 & 0.1 \\
Arsenic & $\mathrm{As}$ & .1 & .1 \\
Cadmium & $\mathrm{Cd}$ & .1 & .1 \\
Chromium & $\mathrm{Cr}$ & 1.0 & .5 \\
Copper & $\mathrm{Cu}$ & 1.0 & .5 \\
Lead & $\mathrm{Pb}$ & 4.0 & .1 \\
Manganese & $\mathrm{Mn}$ & 4.0 & .1 \\
Mercury & $\mathrm{Hg}$ & .02 & .1 \\
Nickel & $\mathrm{Ni}$ & 2.0 & .1 \\
Selenium & $\mathrm{Se}$ & .1 & .1 \\
Zinc & $\mathrm{Zn}$ & 4.0 & .5 \\
\hline
\end{tabular}

When introduced to the aquatic environment, trace elements tend to adsorb to finegrained sediments (Carter, 1997). These traceelement-sorbed particles settle in depositional areas of stream beds where they continue to accumulate, often making sediments the most concentrated pool of trace elements in the aquatic environment (Miller and others, 1992). Increasing concentrations of trace elements in sediment pose a potential threat to benthic organisms and higher trophic-level species that rely on the benthos for food. Non-essential elements, which include $\mathrm{Sb}, \mathrm{As}, \mathrm{Cd}, \mathrm{Cr}, \mathrm{Pb}$, $\mathrm{Hg}$, and $\mathrm{Ni}$, serve no metabolic function in organisms and can become toxic at concentrations greater than the threshold level of the particular organism (Forstner and Wittman, 1983). Even essential elements $\mathrm{Cu}, \mathrm{Fe}, \mathrm{Mn}, \mathrm{Se}$, and $\mathrm{Zn}$, which are vital to metabolic processes, can be toxic to organisms at high concentrations (Forstner and Wittman, 1983). Sb, As, Cd, $\mathrm{Cu}, \mathrm{Cr}, \mathrm{Pb}, \mathrm{Mn}, \mathrm{Hg}$, Ni, Se, and $\mathrm{Zn}$ were selected for detailed analysis because of their relative toxicity, high frequency of detection within the study sites, and association with urbanization and industries located within the study unit.

\section{Organochlorine Compounds}

Organochlorine compounds, which include pesticides and PCBs, have been widely used in the United States since World War II for agricultural purposes and to control diseasecarrying insects and common pests (Harte and others, 1991). Many pesticides, especially organochlorines, have been banned from use in the U.S. since the late 1970's when they were found to have detrimental effects on humans, wildlife, and habitat. Organochlorines tend to share common characteristics, such as environmental persistence, stability, and toxicity (Nadakavukaren, 1995). Once introduced into an aquatic environment, their lipophilic nature allows organochlorines, including PCBs, to ascend through the food chain and bioaccumulate.

Until 1976, when U.S. Environmental Protection Agency (USEPA) restricted chlordane use to termite control, it was used primarily as an insecticide for underground termite control for homes and lawns, and for the control of soil insects in corn fields (New Jersey Department of Environmental Protection and Energy, 1993). It can reach the aquatic environment through drift from aerial spraying, surface runoff, percolation and subsurface seepage from treated lands, misapplication, sewage discharge, and industrial effluents (Canadian Council of Resource and Environment Ministers, 1992). When chlordane is released into the environment it is highly lipophilic, stable in soils, and readily absorbed, for example, through oral and transdermal exposure (U.S. Environmental Protection Agency, 1997). It is persistent, slowly biotransformed, and relatively stable in ultraviolet light. In aquatic environments, chlordane does 
not undergo appreciable hydrolysis, oxidation, or direct photolysis, which also makes it persistent in the adsorbed state. Chlordane was found to cause many serious health effects, principally affecting the liver, nervous system, and immune system. In 1988, USEPA banned the use of chlordane in the U.S (U.S. Environmental Protection Agency, 1997).

With its discovery in 1939, DDT was used as an agricultural insecticide and pesticide. It was banned, however, from general use in the U.S. in 1973 when it was found to accumulate in wildlife, causing substantial decline in numbers and detrimental effects in many species (Ware, 1994). As a result of its relatively long half-life and previous widespread use, DDT is ubiquitous in the environment, adsorbing strongly to soil. It is not readily degraded by microorganisms, enzymes, heat, or ultraviolet light (Ware, 1994). In mammals, DDT is not metabolized or excreted; thus, DDT bioconcentrates in fatty tissue. In an aquatic environment, it adsorbs strongly to the sediment, significantly bioaccumulates and biomagnifies in fish, and does not readily hydrolyze or biodegrade in water. It is, however, still used elsewhere in the world as a pesticide to prevent such insect-borne diseases as malaria and yellow fever.

PCBs are produced synthetically through the chlorination of biphenyl. They tend to be chemically and thermally stable, inert, and dielectric. Because of these qualities, PCBs have been used as plasticizers, hydraulic lubricants, and dielectric fluids in electric capacitors. Because use of PCBs in electric capacitors was within a closed environment, release into the environment was restricted. It was the production and other uses of PCBs as platicizers or components of pesticides that distributed PCBs into the environment (Smith and others, 1988). There are 209 possible congeners, compounds with similar structures and properties, of PCBs whose persistence increases with more highly chlorinated conge- ners. This results in stronger adsorption to organic material, sediment, and soil particles. When PCBs are released into the water, concentrations in sediment and suspended matter tend to be greater than in the associated water column. The lower chlorinated congeners will eventually dissolve into the water column because of their greater water solubility, whereas the higher chlorinated PCB congeners remain adsorbed. PCBs are highly lipid soluble, and they have been shown to bioaccumulate in aquatic organisms and other animals (Ware, 1994; New York State Department of Environmental Conservation, 1985). They have been found to cause many serious health effects, including teratogenicity (Nadakavukaren, 1995). Although production of PCBs was banned in 1979, PCBs are still detected within aquatic environments (Harte and others, 1991).

\section{Acknowledgments}

The authors thank Mark Ayers, Helle Gylling, Anne O'Brien, Jack Pflaumer, and Robert Reiser of the USGS LINJ NAWQA study unit for their assistance in the collection of data and Robin Brightbill and Karen Beaulieu of the USGS for providing additional data from other NAWQA study units. The authors also thank Lars Juergensen and Susan Roe of Environment Canada for providing bed sediment and fish tissue guidelines. Colleague reviews by J. Kent Crawford (USGS) and Sebastian Interlandi (Drexel University) vastly improved the quality of the manuscript.

\section{METHODS OF SAMPLE COLLECTION AND ANALYSIS}

\section{Sample Collection and Processing}

Samples of bed sediment were collected at eight sites in the LINJ study unit in fall 1997 (table 3). The surficial 2.54 inches of the 
sediment was sampled at 5 to 10 depositional areas at each site. The bed-sediment sample was then composited, stirred, and separated into two parts. The part to be analyzed for trace elements was sieved through an acid-washed $63-\mu \mathrm{m}$ mesh nylon cloth with native water into an acid-washed 500-mL plastic bottle. The other part was reserved for analysis of organic chemicals and sieved through a $2.0-\mathrm{mm}$ stainless-steel sieve with a Teflon ${ }^{1}$ policeman into a 1,000-mL glass jar (Shelton, 1996).

Fish were collected at eight sites in the LINJ study unit during fall 1997 . White sucker (Catostomus commersoni) was collected from seven of the eight sites. Creek chubsucker (Erimyzon oblongus), included in the same family (Catostomidae) as white sucker, was selected as the target taxa at Great Egg Harbor River at Sicklerville because its trophic status

\footnotetext{
${ }^{1}$ The use of trade names in this report is for identification purposes only and does not constitute endorsement by the U.S. Geological Survey.
}

was comparable to that of white sucker and white sucker was completely absent at this site (table 3). A pulsed direct-current (DC) backpack electrofishing unit was used to incapacitate fish. Target species were collected and sorted according to size. For analysis of organic compounds, 8 to 10 similarly sized fish were selected, measured, weighed, sexed, checked for anomalies, and frozen on dry ice. At least 5 grams of liver tissue was excised from an additional 8 to 10 fish and frozen on dry ice to be used in trace-element analysis (Crawford and Louma, 1993) (table 3). Liver tissue was selected for the analysis because, although trace elements can bioconcentrate in various organs, they concentrate primarily in the liver (Crawford and Luoma, 1993). Detailed electrofishing and target taxa selection procedures are described in Meador and others (1993) and Crawford and Luoma (1993), respectively. Frozen samples were shipped to the laboratory within 24 hours.

\section{Table 3. Characteristics of fish-tissue and bed-sediment samples collected at selected Long Island-New Jersey study-unit sites}

[Eight fish in each composite sample unless otherwise noted; mm, millimeter; g, gram; --, not applicable]

\begin{tabular}{|c|c|c|c|c|c|c|}
\hline Site name & Site identifier & $\begin{array}{l}\text { Bed- } \\
\text { sediment } \\
\text { collection } \\
\text { date }\end{array}$ & $\begin{array}{c}\text { Fish-tissue } \\
\text { collection } \\
\text { date }\end{array}$ & $\begin{array}{l}\text { Fish type used for } \\
\text { analysis }\end{array}$ & $\begin{array}{l}\text { Average } \\
\text { total length } \\
\text { of fish } \\
(\mathrm{mm})\end{array}$ & $\begin{array}{l}\text { Average } \\
\text { weight of } \\
\text { fish } \\
\text { (g) }\end{array}$ \\
\hline Passaic River near Millington & 01379000 & -- & $10 / 09 / 97$ & White sucker & 346.3 & 430.4 \\
\hline Passaic River at Two Bridges & 01382000 & $10 / 21 / 97$ & -- & -- & -- & -- \\
\hline Saddle River at Ridgewood & 01390500 & $10 / 20 / 97$ & $10 / 08 / 97$ & White sucker & 345.8 & 457.6 \\
\hline Rahway River at Washington Park & 01394200 & -- & $10 / 10 / 97$ & White sucker & 304.0 & 283.1 \\
\hline Rahway River near Springfield & 01394500 & $10 / 07 / 97$ & -- & -- & $\cdots$ & -- \\
\hline Neshanic River at Reaville & 01398000 & $10 / 08 / 97$ & 09/30/97 & White sucker & 308.4 & 320.6 \\
\hline Stony Brook at Princeton & 01401000 & $10 / 09 / 97$ & $10 / 10 / 97$ & White sucker & 380.9 & 547.8 \\
\hline Raritan River at Queens Bridge & 01403300 & $10 / 17 / 97$ & $10 / 07 / 97$ & White sucker & 388.8 & 685.9 \\
\hline Bound Brook at Middlesex & 01403900 & $10 / 14 / 97$ & $10 / 09 / 97$ & White sucker & 297.1 & 278.9 \\
\hline Great Egg Harbor at Sicklerville & 01410784 & $10 / 16 / 97$ & $10 / 14 / 97$ & Creek chubsucker ${ }^{1}$ & 160.9 & 63.9 \\
\hline
\end{tabular}

\footnotetext{
${ }^{1}$ Ten fish in composite sample.
} 
Bed-sediment and fish-tissue samples were analyzed at the U.S. Geological Survey National Water Quality Laboratory (NWQL) in Arvada, Colorado. Detailed protocols for the analytical methods used to determine traceelement concentrations and organochlorine compounds in bed sediment can be found in Arbogast (1996) and Foreman and others (1995), respectively.

The process used for the analysis of organochlorine compounds in composite wholebody fish samples involved homogenization of the tissue into a single composite, collection of an aliquot of the composite by homoextraction with methylene chloride in a soxhlet apparatus, and fractionation by use of an alumina/silica gel. Samples were analyzed by gas chromatography and mass spectrometry. Detailed laboratory procedures are discussed in Leiker and others (1995).

Composites of fish livers were used for analysis of trace elements. Samples were dried, then digested using low-temperature $\left(85^{\circ} \mathrm{C}\right)$ nitric acid and 30 percent hydrogen peroxide solution. The solutions were evaporated to near dryness, then reconstituted with 5-percent nitric acid. Insoluble particles were removed by filtration, and the solutions were analyzed (Hoffman, 1996). Inductively coupled plasma mass spectrometry (ICP-MS), inductively coupled plasma atomic emission spectrometry (ICP-AES), or both were used to analyze for all trace elements except mercury. Determination of mercury concentrations were made by using cold vapor atomic absorbtion spectrophotometry (CV-AAS) (Hoffman, 1996).

For the Passaic and Rahway River Basins, bed sediment and fish tissue were collected in different locations within the drainage basins (table 3). Bed sediment was collected from Passaic River at Two Bridges, a heavily urbanized drainage area (table 1). Tissue samples were collected farther upstream at Passaic River at Millington, a much smaller drainage area where land use is about equally divided between urban-residential and forested. No direct comparisons were made between concentrations in bed sediment and those in fish tissue for these two sites because of significant differences in the size of the drainage areas and land uses; however, the sites were included independently in the overall assessments of bed sediment and fish tissue. For the Rahway River Basin, bed sediment was collected at Rahway River near Springfield, whereas tissue samples were collected upstream at Rahway River at Washington Park. Differences between the Rahway River sites were assumed to be negligible because of their close proximity; therefore, comparisons were made between sampling media (table 1).

\section{Data Analysis}

\section{Linear Regression Analyses of Selected Basin Characteristics}

Land use in the drainage area of each site was determined based on the 1986 Integrated Terrain Unit data. The land-use categories are total urban, urban-residential, urban industrial/ commercial, agricultural, forested, water, wetland, and barren land (New Jersey Department of Environmental Protection, 1996). Population density (people $/ \mathrm{mi}^{2}$ ) was determined for each drainage area by using U.S. Bureau of the Census (1991) data. Linear regression analyses were performed to evaluate the relation of concentrations of trace elements and organochlorines in bed sediment and fish tissue to land-use categories and population density. Relations between concentrations of trace elements and organochlorines in bed sediment and in fish tissue also were examined by using regression analyses. Eight samples were used in the evaluation of trace elements and organochlorine compounds in bed sediment and fish tissue by linear regression analyses. $\mathrm{Sb}, \mathrm{As}, \mathrm{Cd}, \mathrm{Hg}$, and $\mathrm{Se}$ were not analyzed in bed sediment from the Great Egg Harbor River site. Therefore, seven samples 
were used when comparing these trace elements to land use categories and population density. Statistical analyses were considered significant if $p<0.05$. Median concentrations were calculated for each contaminant considered in the study.

\section{Estimation of Baseline Trace-Element Concentrations}

The effects of human activities on the accumulation of trace elements in bed sediment were assessed by comparing trace-element concentrations measured during the current study with baseline concentrations established based on the methods of Velz (1984). Baseline concentrations include natural accumulation in addition to the effects of human activities, including regional atmospheric deposition, which presumably account for low levels of accumulation (Rice, 1999). Velz (1984) states that sediments containing only baseline concentrations of trace elements can be differentiated from sediments affected by human activities by plotting the normal-probability distribution of the concentrations on a probability scale. The plot of a data set consisting of baseline trace-element concentrations would likely yield a straight line. A similar plot from a data set containing concentrations from sediment with known sources of contamination only would likely yield a different slope than that of the baseline data. Integration of these two data sets would produce a plot that would likely yield two straight lines with a distinct change in slope at the point where the lines representing contaminated and baselinesediment trace-element concentrations meet. This point represents the level where baseline concentrations are exceeded and the effects of human activities are evident.

Because there are no unaffected sites in the current study, a more comprehensive data set was used to estimate baseline trace-element concentrations. O'Brien (1997) aggregated data from bed-sediment samples collected during
1976-93 from 295 sites in New Jersey. O'Brien's (1997) trace-element data ${ }^{2}$ were divided into two data sets, one for sites in the Coastal Plain physiographic province and one for non-Coastal Plain sites, and the Velz technique was applied (Velz, 1984). The first observed change in slope was used to estimate baseline concentrations of trace elements in bed sediment from Coastal Plain and nonCoastal Plain sites (table 4). An example of the Velz (1984) technique used to estimate the baseline concentration of copper at a site in the Coastal Plain is shown in figure 2.

A regional assessment of trace-element concentrations in soils was used to corroborate the baseline concentrations established by probability plots (table 4). Fields and others (1992) determined trace-element concentrations in soil from 80 sites with various land-use categories across New Jersey. The traceelement data collected by Fields and others (1992) from rural land-use areas were divided into Coastal Plain and non-Coastal Plain data sets. Median concentrations were calculated for the two data sets and compared with baseline estimates determined by using probability plots.

Although differences in grain size and terrestrial and aquatic environments prohibited direct comparison between soil and bedsediment samples, soil data represented the best reference available to support the baseline trace-element concentrations in sediment estimated based on Velz (1984). Concentrations in soil from Fields and others (1992) were within the same order of magnitude for all trace elements in the Coastal Plain and non-Coastal Plain data sets, with the exception of As in the Coastal Plain (table 4).

\footnotetext{
${ }^{2}$ Although O'Brien's (1997) data include results obtained from different projects based on different analytical techniques and multiple reporting limits, it represents the most comprehensive collection of bedsediment data for New Jersey.
} 
Table 4. Estimated baseline concentrations of selected trace elements in bed sediment and soil from New Jersey Coastal Plain and non-Coastal Plain sites, Long Island-New Jersey study unit

[ND, no data available; ***, median value could not be determined; ---, an appropriate break in the curve could not be determined]

\begin{tabular}{|c|c|c|c|c|c|c|}
\hline \multirow[b]{3}{*}{ Trace element } & \multicolumn{3}{|c|}{ Coastal Plain sittes } & \multicolumn{3}{|c|}{ Non-Coastal Plain sites } \\
\hline & \multicolumn{2}{|c|}{ Probability plots $^{1}$} & \multirow[b]{2}{*}{$\begin{array}{c}\text { Estimated } \\
\text { baseline } \\
\text { concentration in } \\
\text { soil }^{2}\end{array}$} & \multicolumn{2}{|c|}{ Probability plots ${ }^{1}$} & \multirow[b]{2}{*}{$\begin{array}{c}\text { Estimated } \\
\text { baseline } \\
\text { concentration in } \\
\text { soil }^{3}\end{array}$} \\
\hline & $\begin{array}{c}\text { Estimated } \\
\text { baseline } \\
\text { concentration in } \\
\text { bed sediment }\end{array}$ & $\begin{array}{c}\text { Number } \\
\text { of } \\
\text { samples }\end{array}$ & & $\begin{array}{c}\text { Estimated } \\
\text { baseline } \\
\text { concentration in } \\
\text { bed sediment }\end{array}$ & $\begin{array}{c}\text { Number } \\
\text { of } \\
\text { samples }\end{array}$ & \\
\hline $\mathrm{Sb}$ & ND & ND & $* * *$ & ND & ND & $* * *$ \\
\hline As & 3 & 185 & 0.27 & 4 & 321 & 2.55 \\
\hline $\mathrm{Cd}$ & --- & 32 & .011 & --- & 108 & .098 \\
\hline $\mathrm{Cr}$ & 10 & 205 & 3.95 & 10 & 412 & 11.5 \\
\hline $\mathrm{Cu}$ & 10 & 192 & 1.61 & 10 & 457 & 11.1 \\
\hline $\mathrm{Pb}$ & 30 & 214 & 6.75 & 50 & 424 & 17.9 \\
\hline $\mathrm{Mn}$ & 15 & 246 & 5.5 & -- & 544 & 315 \\
\hline $\mathrm{Hg}$ & .07 & 101 & $* * *$ & .16 & 262 & .11 \\
\hline $\mathrm{Ni}$ & 3 & 88 & 1.15 & 20 & 207 & 11.1 \\
\hline Se & -- & 1 & $* * *$ & --- & 14 & .09 \\
\hline $\mathrm{Zn}$ & 10 & 257 & 5.2 & 40 & 540 & 54.2 \\
\hline
\end{tabular}

${ }_{2}^{1}$ Modeled after Velz (1984); data from O'Brien (1997).

${ }^{2}$ Median value of 15 rural Coastal Plain soil samples from Fields and others (1992).

${ }^{3}$ Median value of 17 rural non-Coastal Plain soil samples from Fields and others (1992).

\section{Calculation of Trace-Element Loading from Point Sources}

The effects of point sources on traceelement loading in bed sediment was investigated by calculating trace-element loading in study site drainage areas. Permitted point sources that discharge greater than 1 million gallons of effluent per year from locations upstream from the study sites were identified from point-source data compiled by Robinson and others (1995). Concentrations of As, Cd, $\mathrm{Cr}, \mathrm{Cu}, \mathrm{Pb}, \mathrm{Hg}$, and $\mathrm{Zn}$ typically found in effluents from each industrial category were determined by using data reported by the National Coastal Pollutant Discharge Inventory (NCPDI) (National Occanic and Atmospheric
Administration, 1993). Trace-element loading from point sources was calculated by multiplying NCPDI effluent concentrations by estimated annual point-source discharge. Estimated loads were then divided by the drainage area of the site to standardize the data. The load per square mile of drainage area then was compared to trace-element concentrations in bed sediment by using linear regression analysis.

\section{Calculation of Organochlorines Compounds}

Constituents used to define total organochlorines were chosen to be consistent with those used in other NAWQA studies. Total 


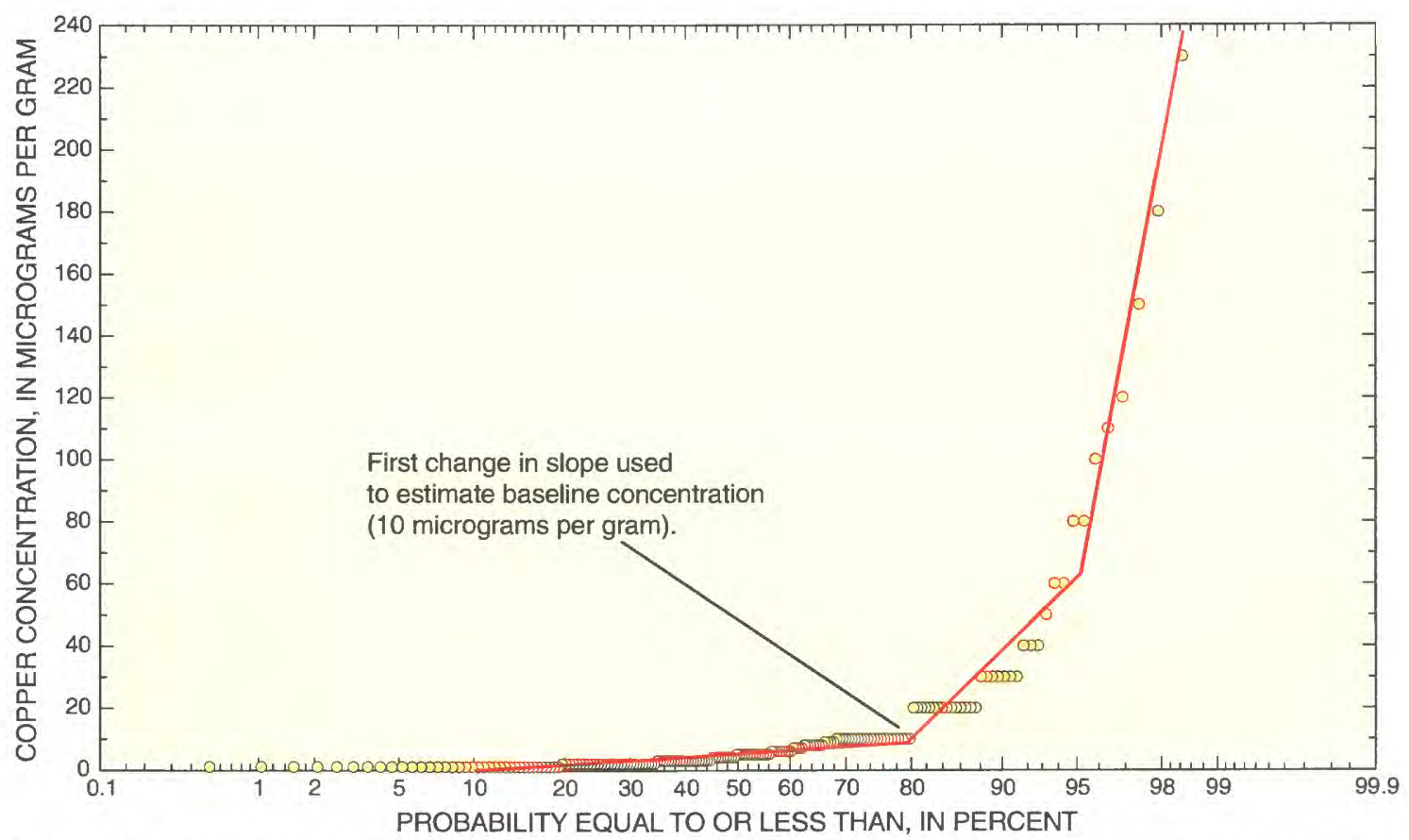

Figure 2. Normal probability distribution of copper from 192 bed-sediment samples collected at sites throughout the New Jersey Coastal Plain.

chlordane was calculated by summing cisnonachlor, trans-nonachlor, oxychlordane, cischlordane, trans-chlordane, and heptachlor epoxide. Total DDT for this study was calculated by summing the $o, p^{\prime}$ - and $p, p^{\prime}$ - congeners of DDT and its breakdown products, the $o, p^{\prime}-$ and $p, p^{\prime}$ - congeners of DDD and DDE. Total PCBs included Aroclors 1242, 1254, and 1260, which were reported as total PCBs by the NWQL. In summing the congeners for the respective total organochlorines, censored values (values less than the method reporting limit) were given a value of zero. Estimated concentrations were calculated as actual concentrations. Minimum reporting limits for organochlorines are listed in table 5.

\section{OCCURRENCE OF TRACE ELEMENTS AND ORGANOCHLORINE COMPOUNDS}

Trace elements or organochlorine compounds were detected in bed-sediment and fish-tissue samples from all of the sites in this study.

\section{Trace Elements in Bed Sediment and Fish Tissue}

\section{Bed Sediment}

One-hundred-percent detection frequency was reported at all sites except Great Egg Harbor River at Sicklerville for the 11 selected trace elements in bed sediment. Samples from the Great Egg Harbor River site were not analyzed for $\mathrm{Sb}, \mathrm{As}, \mathrm{Cd}, \mathrm{Hg}$, and $\mathrm{Se}^{3}$ (fig. 3). The lowest concentrations of $\mathrm{Cr}, \mathrm{Mn}$, and $\mathrm{Ni}$ were present in bed sediment from Great Egg Harbor River site. In addition, $\mathrm{Cu}, \mathrm{Pb}$, and $\mathrm{Zn}$ at this site were equal to or less than median concentrations calculated for all sites in the current study (fig. 3). Concentrations of selected trace elements in samples from Stony Brook and Neshanic River were less than the median concentrations calculated in the study. The lowest concentrations of $\mathrm{Sb}, \mathrm{Cd}, \mathrm{Cu}, \mathrm{Pb}$, $\mathrm{Se}$, and $\mathrm{Zn}$ were in samples from the Stony

\footnotetext{
${ }^{3}$ Additional data on trace elements and organochlorine compounds in bed sediment at the study sites can be found in Deluca and others (1999).
} 
Table 5. Method reporting limits for organochlorine compounds in bed sediment and whole-body-fish tissue

[Units are reported in micrograms per kilogram, dry weight for sediment and micrograms per kilogram, wet weight for fish tissue. $*$, values could not be determined]

\begin{tabular}{lcc}
\hline & \multicolumn{2}{c}{ Method reporting limits } \\
\cline { 2 - 3 } compound & Bed sediment & Fish tissue \\
\hline Cis-nonachlor & 1.0 & 5.0 \\
Trans-nonachlor & 1.0 & 5.0 \\
Oxychlordane & 1.0 & 5.0 \\
Cis-chlordane & 1.0 & 5.0 \\
Trans-chlordane & 1.0 & 5.0 \\
Heptachlor epoxide & 1.0 & 5.0 \\
Total Chlordane & $*$ & $*$ \\
o, $p^{\prime}$-DDD & 1.0 & 5.0 \\
$p, p^{\prime}$-DDD & 1.0 & 5.0 \\
$o, p^{\prime}$-DDE & 1.0 & 5.0 \\
$p, p^{\prime}$-DDE & 1.0 & 5.0 \\
$o, p^{\prime}$-DDT & 2.0 & 5.0 \\
$p, p^{\prime}$-DDT & 2.0 & 5.0 \\
Total DDT & $*$ & \\
Total PCBs & & 5.0 \\
\hline
\end{tabular}

Brook site. The lowest reported concentration of $\mathrm{Hg}(0.03 \mu \mathrm{g} / \mathrm{g})$ was measured in bed sediment from the Neshanic River site, whereas the lowest concentration of As $(4.0 \mu \mathrm{g} / \mathrm{g})$ was measured in bed sediment from the Passaic River at Two Bridges site (fig. 3). Concentrations of trace elements in bed sediment at Rahway River near Springfield and Bound Brook were greater than the study median concentrations for all selected trace elements. Samples from Rahway River near Springfield contained the highest concentrations of 9 of the 11 selected trace elements, second only to the Saddle River site for the highest concentrations of $\mathrm{Mn}$ and $\mathrm{Se}$ $(2,000 \mu \mathrm{g} / \mathrm{g}$ and $1.3 \mu \mathrm{g} / \mathrm{g}$, respectively). Concentrations of the other nine trace elements in bed sediment at the Saddle River site were, in general, greater than the median concentrations (fig. 3).

Concentrations of $\mathrm{Cr}, \mathrm{Cu}, \mathrm{Ni}$, and $\mathrm{Zn}$ measured in bed sediment exceeded baseline concentrations estimated based on Velz (1984) for both Coastal Plain and non-Coastal Plain sites (fig. 3 ). $\mathrm{Pb}$ and $\mathrm{Hg}$ concentrations exceeded estimated baseline concentrations at all sites except Raritan River, Stony Brook, and Neshanic River (fig. 3). Concentrations of As in bed sediment exceeded baseline concentrations at four of the seven sites sampled for As. For the Rahway River near Springfield, Bound Brook at Middlesex, and Saddle River at Ridgewood sites, concentrations in bed sediment exceeded baseline levels for the seven trace elements for which baseline estimates were available (fig. 3 ). Concentrations of trace elements in bed sediment from Great Egg Harbor River exceeded all baseline estimates for Coastal Plain sites (fig. 3).

The strongest relations were found between concentrations in bed sediment and population density (table 6). All selected trace elements except $\mathrm{Cr}, \mathrm{Mn}$, and Se had significant positive relations $(p<0.05)$ to population density (table 6). Of these trace elements, $\mathrm{Sb}$, $\mathrm{Cd}, \mathrm{Cu}, \mathrm{Pb},(p<0.001)$ and $\mathrm{Zn}(p<0.01)$ had the strongest relations to population density.

The presence of trace elements in bed sediment within the study area was related to urban land use. Total urban land use related significantly to all of the selected trace elements except $\mathrm{Cr}, \mathrm{Hg}$, and $\mathrm{Ni}$ (table 6). Se had the strongest relation to total urban land use $(p<0.001)$, but did not relate significantly to any other land-use categories or population density.

By isolating the industrial/commercial part of total urban land use and comparing it to bedsediment concentrations, a stronger relation 

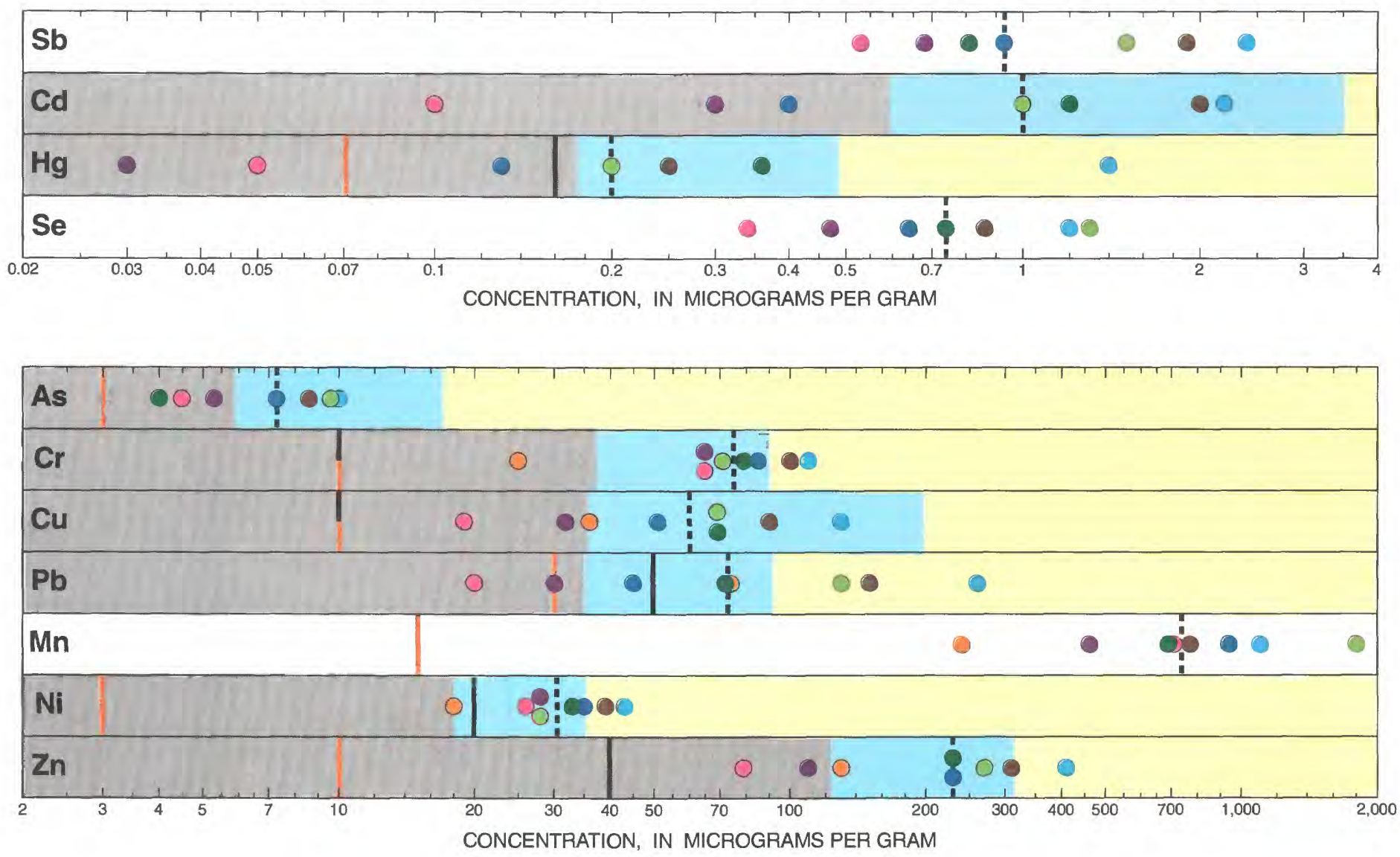

\section{EXPLANATION}

BED-SEDIMENT-QUALITY GUIDELINES

[TEL and PEL guidelines taken from Ecosystem Conservation Directorate Evaluation and Interpretation Branch (1995)]

$<\mathrm{TEL}-$ Concentrations at which adverse-biological effects are expected to occur rarely
$>\mathrm{TEL}<\mathrm{PEL}-$ Concentrations at which adverse-biological effects are expected to occur occasionally
$>\mathrm{PEL}-$ Concentrations at which adverse-biological effects are expected to occur frequently.

BASELINE ESTIMATES AND MEDIAN

[Baseline concentrations were estimated based on Velz (1984)] BASELINE COASTAL PLAIN BASELINE NON COASTAL PLAIN MEDIAN

\section{SAMPLING SITES}

Passaic River at Two Bridges Saddle River at Ridgewood
Rahway River near Springfield

Neshanic River at Reaville
Stony Brook at Princeton

Raritan River at Queensbridge
Bound Brook at Middlesex

Great Egg Harbor River at Sicklerville

Figure 3. Concentrations of selected trace elements in bed sediment, estimated baseline concentrations, sediment-quality guidelines, and median concentrations in the Long Island-New Jersey study unit. 
Table 6. Linear relation probabilities of trace-element concentrations in bed sediment to land use and population density at selected Long Island-New Jersey study-unit sites

[ $p$-value is derived from linear regression analysis; values in bold are considered to be significant; $*, p<0.05 ; * *, p<0.01 ; * * *, p<0.001]$

\begin{tabular}{ccccc}
\hline & & \multicolumn{3}{c}{ Land use } \\
\cline { 3 - 5 } Trace element & $\begin{array}{c}\text { Number of } \\
\text { samples }\end{array}$ & Total urban & $\begin{array}{c}\text { Urban industrial } \\
\text { commercial }\end{array}$ & Population density \\
\hline $\mathrm{Sb}$ & 7 & $\mathbf{0 . 0 1 6 3 ^ { * }}$ & $\mathbf{0 . 0 1 0 0 ^ { * }}$ & $\mathbf{0 . 0 0 0 2}^{* * *}$ \\
$\mathrm{As}$ & 7 & $.0337^{*}$ & .1806 &. $\mathbf{0 4 7 2}^{*}$ \\
$\mathrm{Cd}$ & 7 & $.0287^{*}$ & $.00002^{* * *}$ &. $\mathbf{0 0 0 4}^{* * *}$ \\
$\mathrm{Cr}$ & 8 & .1846 & .0547 & $.0657^{*}$ \\
$\mathrm{Cu}$ & 8 & $.0128^{*}$ & $.0013^{* *}$ & $.0005^{* * *}$ \\
$\mathrm{~Pb}$ & 8 & $.0071^{* *}$ & $.0049^{* *}$ & $.0001^{* * *}$ \\
$\mathrm{Mn}$ & 8 & $.0385^{*}$ & .5548 & $.3781^{*}$ \\
$\mathrm{Hg}$ & 7 & .1759 & .0728 & $.0372^{*}$ \\
$\mathrm{Ni}$ & 8 & .2070 & $.0342^{*}$ & $.0464^{*}$ \\
$\mathrm{Se}$ & 7 & $.0010^{* *}$ & .1248 & .0572 \\
$\mathrm{Zn}$ & 8 & $.0098^{* *}$ & $.0052^{* *}$ & $.0024^{* *}$ \\
\hline
\end{tabular}

was established (table 6). Significant relations $(p<0.05)$ were determined between industrial/ commercial land use and bed-sediment concentrations of $\mathrm{Sb}, \mathrm{Cd}, \mathrm{Cu}, \mathrm{Pb}, \mathrm{Ni}$, and $\mathrm{Zn}$ (table 6). No significant relations $(p>0.05)$ were determined between the selected trace elements and the remaining land-use categories. Cr was not significantly related to population density or any of the land-use categories investigated in this study (table 6).

An investigation of permitted point source discharges upstream from the sites indicated no significant relation $(p>0.05)$ between As, Cd, $\mathrm{Cr}, \mathrm{Pb}, \mathrm{Hg}$, and $\mathrm{Zn}$ concentrations in bed sediment and annual trace-element loading from point sources. A significant relation $(p<0.028)$ was determined, however, between bed-sediment concentrations of $\mathrm{Cu}$ and annual $\mathrm{Cu}$ loading from point sources.

\section{Fish Tissue}

$\mathrm{Cu}, \mathrm{Mn}, \mathrm{Hg}$, Se, and $\mathrm{Zn}$ were detected in white-sucker liver samples from all seven sites where white sucker were available (table 7$)^{4}$. $\mathrm{Cr}$ was detected in livers from all sites except Raritan River. Pb was detected only at Rahway River at Washington Park, and As was detected only at Saddle River. $\mathrm{Sb}$ and Ni were not detected in livers from any sites. At Great Egg Harbor River, all of the selected trace elements with the exception of $\mathrm{Sb}, \mathrm{As}, \mathrm{Cr}$, and $\mathrm{Ni}$ were detected in creek chubsucker livers (table 7).

The results of fish-tissue analysis revealed wide variation in the bioaccumulation of trace elements among sites (table 7). Trace-element concentrations at Great Egg Harbor River,

\footnotetext{
${ }^{4}$ Additional data on trace elements and organochlorine compounds in fish tissue are stored in the U.S. Geological Survey Water-Quality data base maintained by the USGS at the New Jersey District office in West Trenton, N.J.
} 


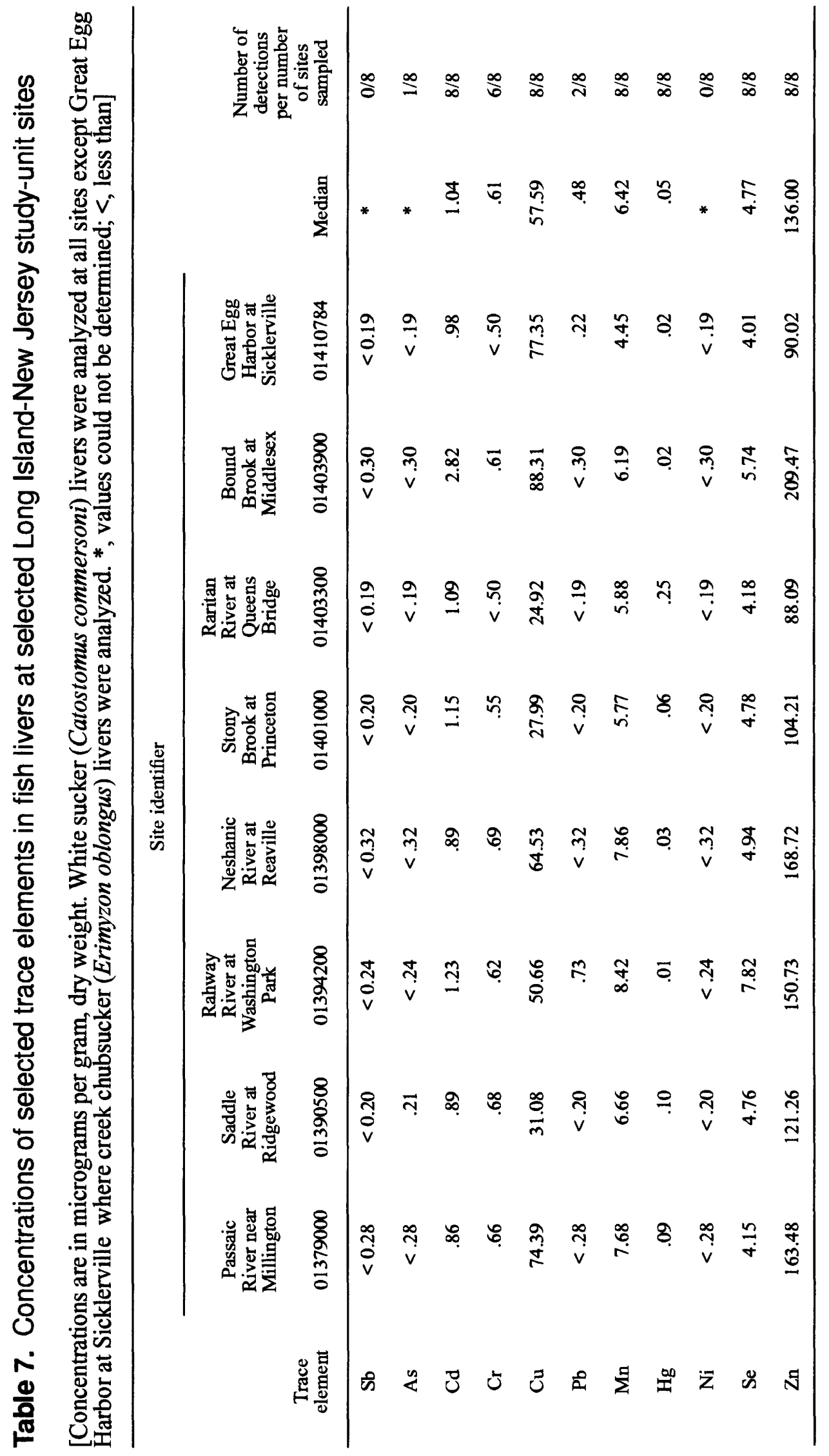


except $\mathrm{Cu}$, were lower than median concentrations for all other sites. Trace-element concentrations in fish tissue from Neshanic River at Reaville, Passaic River at Millington, and Rahway River at Washington Park were generally greater than median concentrations (table 7). At the remaining sites, trace-element concentrations in fish tissue varied with respect to median concentrations. Results of linearregression analyses used to compare concentrations in fish tissue to those in bed sediment indicated no significant relations ( $p>0.05$ ), and no significant relations were indicated between concentrations in fish tissue and land-use categories or population density $(p>0.05)$.

\section{Organochlorine Compounds in Bed Sedi- ment and Fish Tissue}

\section{Bed Sediment}

Total chlordane was detected in samples of bed sediment from five of eight sites (table 8). DDT in bed sediment was detected at seven sites. Total PCBs were detected in bed sediment at only four sites. The highest concentrations of total chlordane $(42.9 \mu \mathrm{g} / \mathrm{kg})$ and DDT $(60.6 \mu \mathrm{g} / \mathrm{kg})$ in bed sediment were present in samples from Rahway River near Springfield, and the highest total PCB concentrations $(420 \mu \mathrm{g} / \mathrm{kg})$ in bed sediment were present in samples from Saddle River at Ridgewood. No significant relations were indicated for chlordane, DDT, and PCB concentrations between fish tissue and bed sediment (table 9). Chlordane and DDT concentrations in bed sediment were significantly correlated with population density $(p<0.047$ and $p<0.001$, respectively) (table 9). Significant relations were determined between chlordane and PCB concentrations in bed sediment and total urban land use ( $p<0.018$ and $p<0.022$, respectively) and between chlordane concentrations in bed sediment and urban industrial/commercial land use $(p<0.013)$ (table 9).

\section{Fish Tissue}

Total chlordane was detected in fish tissue from seven sites (table 10). DDT and total PCBs were found in fish tissue from all sites. The highest concentrations of total chlordane $(322 \mu \mathrm{g} / \mathrm{kg})$, DDT $(259 \mu \mathrm{g} / \mathrm{kg})$, and PCBs $(1800 \mu \mathrm{g} / \mathrm{kg})$ in fish tissue were present in samples from Stony Brook at Princeton, Saddle River at Ridgewood, and Bound Brook at Middlesex, respectively (table 10). No significant relations were determined between chlordane, DDT, or PCB concentrations in fish tissue and any land use or population density (table 9).

\section{ASSESSMENT OF TRACE ELEMENTS AND ORGANOCHLORINE COMPOUNDS}

Basin and stream conditions that affect the occurrence of trace elements and organochlorines in bed sediment and fish tissue are discussed in this section.

\section{Trace Elements in Bed Sediment and Fish Tissue}

\section{Bed Sediment}

Densely populated areas could contribute to trace-element loading in aquatic environments. Stankowski (1974) indicates that the percentage of impervious cover is a function of the population density of the watershed. The volume of runoff after a storm is highly correlated with the percentage of impervious surfaces within the watershed (Schueler, 1994). A study investigating the effects of runoff on trace-element loading reported increased concentrations of $\mathrm{Cu}, \mathrm{Pb}$, and $\mathrm{Zn}$ in streams draining two heavily urbanized watersheds in Lodi, N.J., following a storm (Fornster and Wittman, 1983). Trace elements atmospherically deposited on impervious surfaces could be mobilized into the aquatic environment 


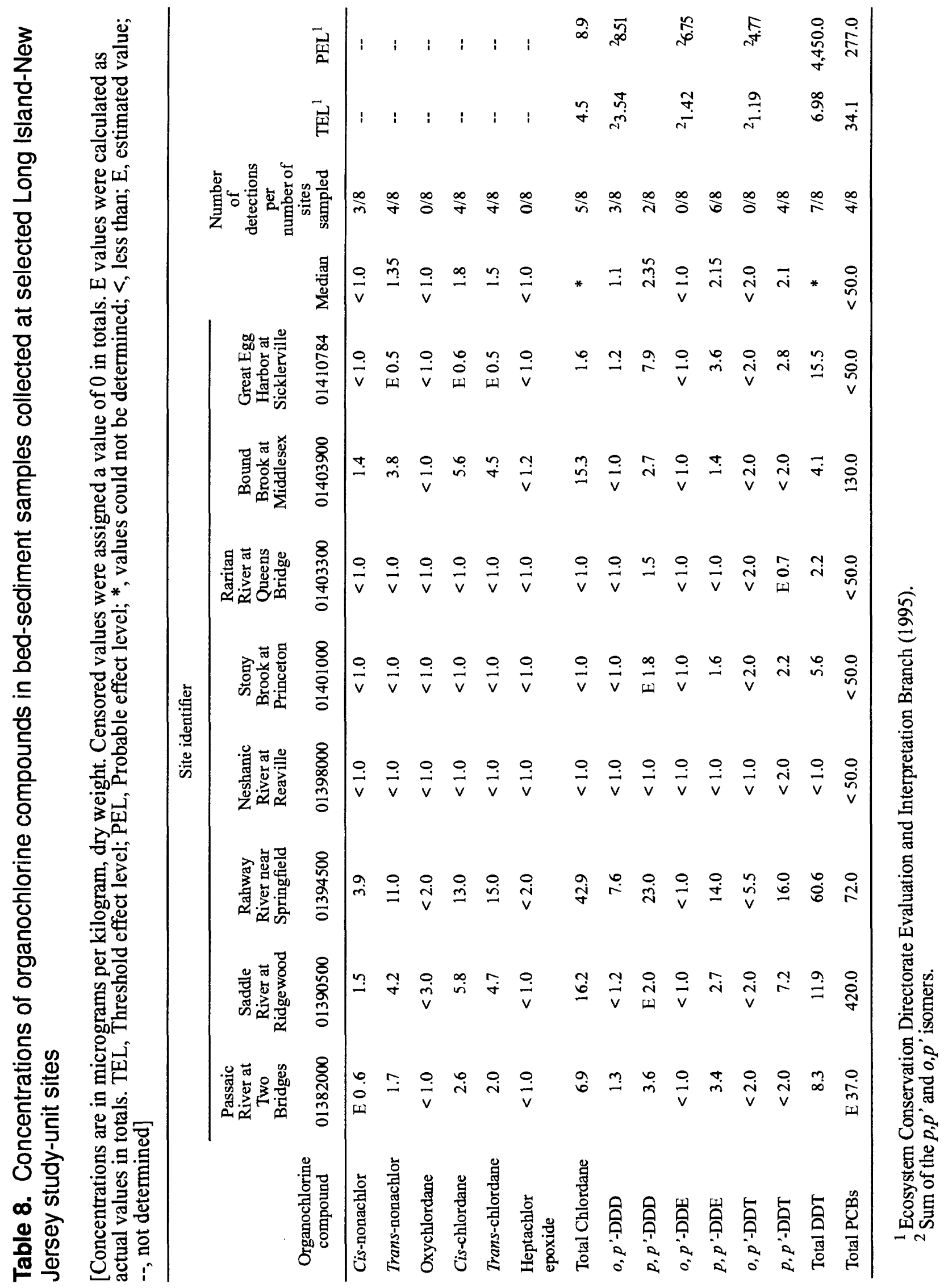


Table 9. Linear relation probabilities of organochlorine compounds in fish tissue and bed sediment to basin characteristics at selected Long Island New Jersey study-unit sites

[Eight fish were used in each composite sample; $p$-values were derived from linear regression analysis; values in bold are considered to be significant; *, $\left.p<0.05 ;{ }^{*}, p<0.01\right]$

\begin{tabular}{|c|c|c|c|c|c|c|}
\hline \multirow[b]{2}{*}{ Basin characteristics } & \multicolumn{3}{|c|}{ Fish tissue } & \multicolumn{3}{|c|}{ Bed sediment } \\
\hline & Chlordane & DDT & PCBs & Chlordane & DDT & PCBs \\
\hline Population density & 0.4417 & 0.7598 & 0.2712 & $0.0014^{\star \star}$ & $0.0472 *$ & 0.4035 \\
\hline Urban industrial/commercial land use & .6022 & .8681 & .1829 & $.0175^{\star}$ & .1234 & .5543 \\
\hline Total urban land use & .2502 & .3362 & .5881 & $.0133^{*}$ & .1586 & $.0223 *$ \\
\hline
\end{tabular}

through stormwater runoff. The relation between population density and runoff from impervious surfaces could be a contributing factor to the strong relation between population density and trace-element concentration in bed sediment observed in the current study (table 6).

The results of the regression analyses illustrate the effects of urbanization on traceelement concentrations in bed sediment. Concentrations of 8 of the 11 selected trace elements were significantly related to total urban land use (table 6). Fields and others (1992) reported a similar relation between urban land use and trace-element concentrations in New Jersey soils; all trace elements except beryllium, $\mathrm{Cr}$, and $\mathrm{Se}$ were significantly higher in urban soils than in rural soils (Fields and others, 1992).

Industrial and commercial emissions also appear to affect trace-element concentrations in bed sediment. Significant relations determined in this study between urban industrial/commercial land use and concentrations of $\mathrm{Sb}, \mathrm{Cd}, \mathrm{Cu}$, $\mathrm{Pb}, \mathrm{Ni}$, and $\mathrm{Zn}$ in bed sediment are consistent with the extensive industrial and commercial applications of these elements (table 6) (Harte and others, 1991; Winter, 1998; O'Brien, 1997; Brigham and others, 1997; Forstner and Wittman, 1983).
The results of the regression analyses were consistent with the findings of O'Brien (1997) who compared basin characteristics to concentrations of $\mathrm{As}, \mathrm{Cr}, \mathrm{Cu}, \mathrm{Fe}, \mathrm{Pb}, \mathrm{Mn}, \mathrm{Ni}$, and $\mathrm{Zn}$ in bed-sediment samples collected at 295 sites in New Jersey. The presence of $\mathrm{Cu}, \mathrm{Pb}$, and $\mathrm{Zn}$ in bed sediment was found to be most strongly related to population density (table 6) (O'Brien, 1997). Concentrations of $\mathrm{Cr}$ in bed sediment were found to be more closely related to underlying geology than to differences in land use among drainage areas (O'Brien, 1997).

The results of the regression analyses indicated that non-point sources had a greater effect on trace-element loading in bed sediment than point sources. $\mathrm{As}, \mathrm{Cd}, \mathrm{Cr}, \mathrm{Pb}, \mathrm{Hg}$, and $\mathrm{Zn}$ loading from point sources were not significantly related $(p>0.05)$ to concentrations in bed sediment. In the study of New Jersey soils, Fields and others (1992) determined that traceelement concentrations decreased along a landuse gradient from urban to rural soils. The sites sampled in the study were not directly affected by industry or other point sources, indicating that the decreasing gradient could be attributed to non-point source distribution of trace elements. Similar relations between urban land use and trace-element concentrations in bed sediment were observed in the current study and also could be attributed to non-point sources. 


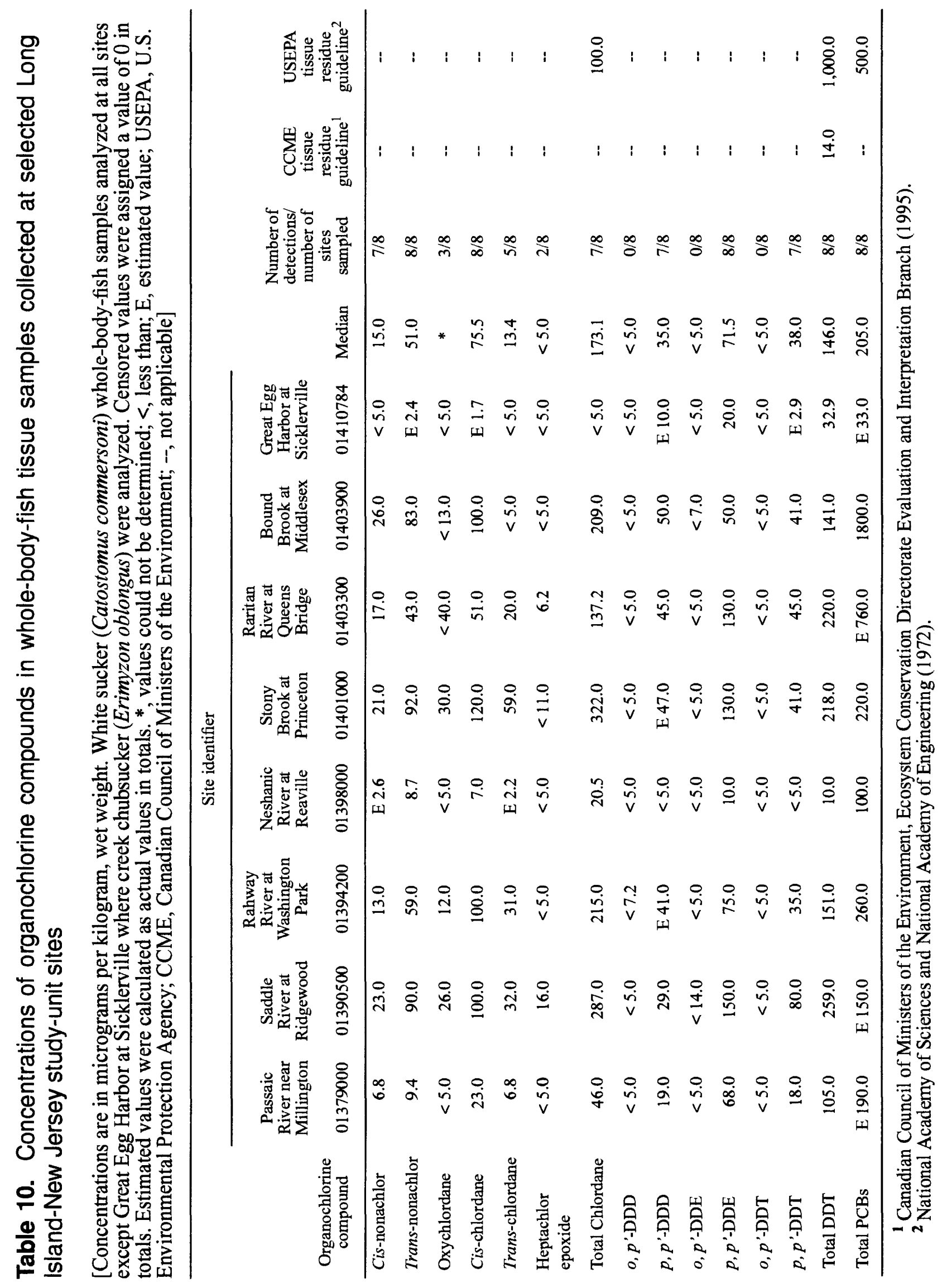


The significant positive relation $(\mathrm{p}<0.028)$ identified between $\mathrm{Cu}$ concentrations in bed sediment and estimated annual $\mathrm{Cu}$ loading from point sources is consistent with the findings of O'Brien (1997). The probability of detecting concentrations of $\mathrm{Cu}$ greater than $15 \mu \mathrm{g} / \mathrm{g}$ in bed sediment as a function of total flow from point sources was significant (O’Brien, 1997).

\section{Fish Tissue}

Consumption of contaminated fish tissue poses a health risk to humans, as well as wildlife. Concentrations of trace elements in fish livers and concentrations of organochlorine compounds in whole fish are generally greater than in fish-fillet samples because muscle tissue contains lower concentrations of these substances (Crawford and Luoma, 1993; Schmitt and others, 1981). Because fillets were not analyzed for trace elements or organochlorine compounds, the values reported are not appropriate for human-health risk assessment. Fish tissue analysis, however, is important in the evaluation of trace elements in the aquatic environment because it is used to determine the amounts of trace elements that are biologically available.

Because trace elements concentrate in liver tissue, the low detection frequency of $\mathrm{Sb}$, $\mathrm{As}, \mathrm{Pb}$, and $\mathrm{Ni}$ in liver samples indicates that these trace elements are less available to fish than the remaining trace elements (table 7). Sb, which was not detected in livers at any of the sites, probably is the least available. Studies assessing the bioavailablity of Sb have shown that it is only slightly bioaccumulated (U.S. Environmental Protection Agency, 1979). Other NAWQA study units (for example, Carter, 1997; Coles, 1996; Harris, 1997; Durlin and Schaffstall, 1995 and 1996) did not report detectable concentrations of $\mathrm{Sb}$ in any of the white sucker livers that were analyzed, although it was present in detectable concentrations in bed sediment. As can bioaccumulate through food and water; however, the degree of accumulation is generally below detection limits (U.S. Environmental Protection Agency, 1979). $\mathrm{Pb}$ has been demonstrated to bioaccumulate in a variety of organisms, especially in water with pH 6.0 or less. In more acidic environments, divalent $\mathrm{Pb}$, the most biologically available form, is at its highest concentrations (U.S. Environmental Protection Agency, 1979). At Great Egg Harbor River, one of two sites where $\mathrm{Pb}$ was detected, water-column $\mathrm{pH}$ was 5.8 at the time of sampling; $\mathrm{pH}$ at other sites ranged from 7.0 to 7.6. Although $\mathrm{Ni}$ has been detected in whole-fish tissue samples, it is not considered to bioaccumulate in significant amounts (Saiki and May, 1988; Winger and others, 1990; U.S. Environmental Protection Agency, 1979).

Other NAWQA study units generally reported detectable concentrations in less than one-half of the white sucker livers analyzed for $\mathrm{Ni}$, although it was prevalent in bed sediment at each site (Carter, 1997; Coles, 1996; Harris, 1997; Durlin and Schaffstall, 1995, 1996).

All the remaining trace elements, with the exception of $\mathrm{Cr}$ which was not detected at Raritan River or Great Egg Harbor River, were found to concentrate in fish livers at all sites. Trace elements preferentially taken up by organisms for metabolism ( $\mathrm{Cu}, \mathrm{Mn}, \mathrm{Se}$, and $\mathrm{Zn})$ were detected in fish livers at concentrations generally one to two orders of magnitude greater than those considered to be non-essential. Of the selected trace elements, Se was the only element for which median concentrations in fish tissue exceeded median concentrations in bed sediment (fig. 3; table 7).

In the current study, no significant relations were determined between trace-element concentrations in fish tissue and those in bed sediment. Other NAWQA study units also reported weak or no significant relations between bed-sediment and fish-tissue traceelement concentrations (Breault and Harris, 1997; Carter, 1997). Miller and others (1997) 
concluded that concentrations of $\mathrm{Cu}$ and $\mathrm{Zn}$ in water were a better indicator than concentrations in bed sediment of the accumulation of $\mathrm{Cu}$ and $\mathrm{Zn}$ in fish tissue.

\section{Organochlorine Compounds in Bed Sedi- ment and Fish Tissue}

Organochlorine compounds tend to be the most persistent anthropogenic compounds in the environment. Most of these compounds have low vapor pressure and are not water soluble (Nadakavukaren, 1995). These compounds also tend to have low volatility in water; therefore, they tend to sorb to organic carbon suspended in the water column and in bed sediment (Stackelberg, 1997). In this study, most of the organochlorine compounds analyzed for in bed sediment were present at concentrations less than the method reporting limit (table 8). The three classes of organochlorine compounds most commonly detected were chlordane, DDT, and PCBs.

Whole-body fish tissue was a more sensitive indicator of the presence of organochlorines than bed sediment because of the higher detection frequencies of, and higher concentrations in, fish tissue. Relations between concentrations of chlordane, DDT, and PCBs in fish tissue and that in bed sediment were generally weak $(p=0.383,0.921$, and 0.895 , respectively). There were, however, strong relations $(p<0.05)$ between organochlorine concentrations in bed sediment and population density (table 9). No relation was found between concentrations in fish tissue and population density (table 9).

Trans-nonachlor is the least degradable of all the chlordane components; therefore, the presence of this compound relative to other forms of chlordane signals that the input of chlordane was not recent (Coles, 1998). Transnonachlor and cis-chlordane were detected most frequently and at higher concentrations in both bed sediment and fish tissue than other components at all sites except Great Egg Harbor River (tables 8 and 10). Bioaccumulation is an important removal process of chlordane in the aquatic environment. One study found that the trans-isomer was eliminated 1.8 times faster than the cis-isomer in northern redhorse suckers (Moxostoma macrolepidotum) (Canadian Council of Resource and Environment Ministers, 1992). Oxychlordane, which has no insecticidal properties, is more persistent and toxic than its parent compound. It is a dominant metabolite of chlordane in mammalian systems, residing as major terminal residue in animal tissues and milk (Canadian Council of Resource and Environment Ministers, 1992). Oxychlordane was detected in fish tissue from three sites in the LINJ study basin, but was less than the method reporting limit in bed sediment (tables 8 and 10).

USEPA tissue-residue guidelines, developed for the protection of fish-eating wildlife, were exceeded at five sites (table 10) (National Academy of Sciences and National Academy of Engineering, 1972). The highest total chlordane concentration in fish tissue was found at Stony Brook at Princeton, but concentrations in bed sediment were less than the method reporting limit (tables 8 and 10). Total chlordane concentrations in bed sediment increased with increasing population density (table 9). Other studies yielded similar results (Stackelberg, 1997; Coles, 1998); as population density and urban-residential land use increased, so did chlordane concentrations.

Technical grade DDT can contain 70 to 73 percent of the $p, p^{\prime}$-isomer and 12 to 21 percent of the $o, p^{\prime}$-isomer (Canadian Council of Resource and Environment Ministers, 1992). Of the total DDT metabolites, the $p, p^{\prime}$-isomers were detected more frequently and at greater concentrations than the $o . p^{\prime}$-isomers (tables 8 and 10). Because DDE is an extremely stable metabolite of DDT, the presence of large amounts of DDE in a system signifies that the 
DDT contamination is not recent (Aguilar, 1984). Total DDE concentrations in fish tissue were greater than concentrations of all other DDT products (table 10). DDE is slowly transformed into products that are excreted and, like its parent compound DDT, has low water solubility, which contributes to low rates of excretion and high persistence in the lipid phase of tissues in living organisms (Canadian Council of Resource and Environment Ministers, 1992). Although DDT was used in the past primarily as an agricultural insecticide, total DDT concentrations in bed sediment were significantly related to population density $(p<0.047)$ (table 9). This relation could result from a shift from agricultural to residential land use, which has occurred at many of the selected sites. Samples from Neshanic at Reaville, a predominantly agricultural site, contained total DDT concentrations in bed sediment and fish tissue less than CCME and USEPA guidelines (tables 8 and 10).

Sorption to sediments is the predominant mechanism for removing PCBs from the water column (U.S. Environmental Protection Agency, 1979). PCBs were detected at the Passaic River, Saddle River, Rahway River, and Bound Brook sites (table 8). PCBs are soluble in lipids and tend to accumulate in fatty tissues. Therefore, low levels of PCBs contamination in aquatic systems can result in the bioaccumulation of relatively high PCBs levels in biota (Canadian Council of Resource and Environment Ministers, 1992). The highest PCB concentrations in fish tissue were found at Bound Brook at Middlesex (table 10). The source of these high concentrations of PCBs at Bound Brook has been linked to a Superfund site (New Jersey Department of Environmental Protection, 1998).

\section{Importance of Sampling Multiple Media}

The results of analyses for trace element and organochlorines in bed sediment and fish tissue illustrate the importance of sampling multiple media. Trace-element concentrations in bed sediment from the Neshanic River site were less than median values for the study (fig. 3). Concentrations in fish-tissue samples from same site, however, were generally greater than median values. At Rahway River near Springfield, concentrations of $\mathrm{Hg}$ in bed sediment were the highest reported in the study $(1.4 \mu \mathrm{g} / \mathrm{g})$. Concentrations of $\mathrm{Hg}$ in fish tissue from Rahway River at Washington Park, however, were the lowest reported in the study $(0.01 \mu \mathrm{g} / \mathrm{g})$. Similar results were obtained from the analysis for organochlorines. These results indicated that samples from both media are needed to provide an accurate description of contaminants in aquatic systems.

\section{POTENTIAL FOR ADVERSE BIOLOGICAL EFFECTS}

Currently, the U.S. has no standards for use in assessing the potential for adverse biological effects due to contaminant-enriched freshwater sediment. Long and Morgan (1991) developed an approach for assessing coastal marine and estuarine sediments for their potential effects on the biota as a part of the National Status and Trends Program. The Canadian Council of Ministers of the Environment (CCME) modified this approach to develop guidelines for marine and freshwater sediment. The CCME modified approach includes the use of models of equilibrium partitioning in sediments, sediment quality assessment values from other jurisdictions, spiked sediment toxicity tests, and field studies (Ecosystem Conservation Directorate Evaluation and Interpretation Branch, 1995).

Two assessment levels were estimated based on the CCME modified approach, (1) the threshold effect level (TEL), which represents the concentration below which adverse effects are expected to occur rarely, and (2) the probable effect level (PEL), which represents 
the concentration above which adverse effects are expected to occur frequently. Concentrations between TELs and PELs are values at which occasional adverse effects are expected (Ecosystem Conservation Directorate Evaluation and Interpretation Branch, 1995). Adverse biological effects are generally defined as effects that are considered to be negative to the organism (for example, mortality, reduction in growth, decreased reproductive success) (Lars Juergensen, Environment Canada, oral commun., 1999). Bulk sediment samples were used in developing the TEL and PEL guidelines. The TEL and PEL values were used with caution when compared with the trace-element concentrations in sieved bed-sediment samples in the current study because fine-grained sediment typically contains higher traceelement concentrations than does bulk sediment. A detailed explanation of the derivation of these guidelines can be found in Ecosystem Conservation Directorate Evaluation and Interpretation Branch (1995).

\section{Trace Elements}

In the current study, Ni concentrations in bed sediment represented the greatest potential for adverse biological effects. Ni concentrations greater than or equal to TELs were measured at all eight sites; Ni concentrations exceeded PELs at two of eight sites (fig. 3). Cr, $\mathrm{Cu}, \mathrm{Pb}$, and $\mathrm{Zn}$ concentrations surpassed TELs for at least six of the eight sites. Concentrations of $\mathrm{As}, \mathrm{Cd}$, and $\mathrm{Hg}$ in bed sediment exceeded TELs at only four of seven sites (fig. 3). PELs were exceeded by $\mathrm{Hg}$ and $\mathrm{Zn}$ concentrations at one site, by $\mathrm{Ni}$ and $\mathrm{Cr}$ at two sites, and by $\mathrm{Pb}$ at three sites. Concentrations of $\mathrm{As}, \mathrm{Cd}$, and $\mathrm{Cu}$ did not exceed PELs at any site.

The site at Rahway River near Springfield had the greatest potential for adverse biological effects associated with trace-element concentrations in bed sediment. Concentrations of all trace elements were greater than TELs, and all trace elements with the exception of As, Cd, and $\mathrm{Cu}$ exceeded PELs (fig. 3). Large discrepancies between measured concentrations and guidelines for trace elements in bed sediment were noted for $\mathrm{Pb}$ and $\mathrm{Hg}$; at the Rahway River near Springfield site, $\mathrm{Pb}$ and $\mathrm{Hg}$ concentrations were nearly three times their respective PELs (fig. 3). Concentrations of all trace elements for which there are established TEL and PEL guidelines exceeded TELs at the Bound Brook and Saddle River sites. PELs were exceeded for $\mathrm{Cr}, \mathrm{Pb}$, and $\mathrm{Ni}$ at the Bound Brook site and for $\mathrm{Pb}$ at the Saddle River site. Concentrations in bed-sediment samples at Stony Brook and Neshanic River exceeded TELs only for $\mathrm{Cr}$ and $\mathrm{Ni}$. For all remaining sites, trace-element concentrations were greater than or equal to TELs, but did not exceed PELs for most of the trace elements analyzed.

\section{Organochlorine Compounds}

Although chlordane, DDT, and PCBs have been banned from use in the U.S., concentrations at three sites (Passaic River, Saddle River, and Rahway River) exceeded TELs for all three compounds. TELs for total chlordane were exceeded at the Passaic River, Saddle River, Rahway River, and Bound Brook sites; PELs also were exceeded at these sites, excluding the Passaic River site (table 8). Total DDT concentrations in bed sediment at the Passaic River, Saddle River, Rahway River, and Bound Brook at Middlesex sites exceeded TELs (Table 8).

Concentrations of PCBs in bed sediment from the Passaic River, Saddle River, Rahway River, and Bound Brook sites exceeded TELs; Saddle River at Ridgewood had the highest concentration $(420 \mu \mathrm{g} / \mathrm{kg})$, which exceeded PELs (table 8).

\section{Synergistic Effects}

The toxicity of trace elements and organochlorines may be exacerbated by potential 
synergistic effects. Synergism occurs when the effects of exposure to multiple contaminants are greater than the sum of the expected effects from exposure to each individual contaminant. Although the toxicity of multiple contaminants is largely unknown, the mixture toxicity of trace elements has been investigated. Laboratory water-column experiments have demonstrated the significant synergistic effect of $\mathrm{Cu}$ and $\mathrm{Zn}$ in water on fathead minnows (Pimephales promelas) (Fornster and Wittman, 1983). USEPA studies have found that the acute toxic effects of aldrin, endrin, and methoxychlor with chlordane were greater than the additive sum of the individual toxicities (U.S. Environmental Protection Agency, 1997). When multiple contaminants exceed established sediment-quality guidelines, potential synergistic effects of trace elements and organochlorines are an additional environmental concern.

\section{SUMMARY}

Bed-sediment and fish-tissue samples were collected in fall 1997 and analyzed to determine the concentrations of 11 trace elements and 3 organochlorine compounds. Sb, $\mathrm{As}, \mathrm{Cd}, \mathrm{Cr}, \mathrm{Cu}, \mathrm{Pb}, \mathrm{Mn}, \mathrm{Hg}, \mathrm{Ni}, \mathrm{Se}, \mathrm{Zn}$, chlordane, DDT, or PCBs were present in samples of bed sediment or fish tissue from all ten sites throughout the study area. Urban growth in the LINJ study unit appears to have contributed to a decline in stream-bed-sediment quality. Results of regression analyses indicated that urban land use and population density were significantly related to trace-element and organochlorine concentrations in bed sediment.

Bed-sediment samples from the Great Egg Harbor River at Sicklerville site were not analyzed for $\mathrm{Sb}, \mathrm{As}, \mathrm{Cd}, \mathrm{Hg}$, and $\mathrm{Se}$; however, all 11 trace elements were detected in bed sediment at all other sites. The presence of all trace elements, with the exception of $\mathrm{Cr}$, was significantly related to urban land use or popu- lation density. Concentrations of $\mathrm{Cr}, \mathrm{Cu}$, and $\mathrm{Zn}$ in bed sediment exceeded estimated baseline concentrations at all sites. No significant relations were found between concentrations of $\mathrm{As}, \mathrm{Cd}, \mathrm{Cr}, \mathrm{Pb}, \mathrm{Hg}$, and $\mathrm{Zn}$ in bed sediment and trace-element loading from point sources, which could indicate a greater influence of nonpoint sources.

$\mathrm{Cu}, \mathrm{Mn}, \mathrm{Hg}$, and $\mathrm{Se}$ were detected in all samples of white sucker livers. $\mathrm{Cd}, \mathrm{Cu}, \mathrm{Pb}, \mathrm{Mn}$, $\mathrm{Hg}$, Se, and $\mathrm{Zn}$ were detected in all samples of creek chubsucker livers. No significant relations were determined between traceelement concentrations in fish tissue and those in bed sediment or between trace-element concentrations in fish tissue and land use or population density.

Chlordane was detected in fish-tissue samples from all sites except Great Egg Harbor River; DDT and PCBs were detected in fishtissue samples from all sites. DDT did not exceed USEPA tissue-residue guidelines for fish-eating wildlife at any site. Concentrations of chlordane and PCBs exceeded USEPA guidelines at five sites and two sites, respectively. Chlordane was detected in bed sediment at five sites, DDT at seven sites, and PCBs at four sites. Concentrations of DDT and chlordane in bed sediment were significantly related to population density. No significant relations were indicated between organochlorine concentrations in fish tissue and those in bed sediment or between concentrations in fish tissue and land use or population density.

TELs are concentration levels below which adverse biological effects are rare; PELs are the concentration levels above which adverse biological effects are frequent. Concentrations between TELs and PELs are levels at which adverse biological effects occasionally occur. All sites were found to have the potential for adverse biological effects associated with concentrations of at least two trace elements in bed sediment. Concentrations of $\mathrm{As}, \mathrm{Cd}, \mathrm{Cr}, \mathrm{Cu}, \mathrm{Pb}, \mathrm{Hg}, \mathrm{Ni}$, and $\mathrm{Zn}$ exceeded 
TELs in 77 percent of the samples; concentrations of Ni were equal to or exceeded TELs at all sites. Concentrations of chlordane, DDT, and PCBs in 50 percent of the bed-sediment samples exceeded TELs. Concentrations of all three organochlorine compounds in bedsediment samples from Passaic River at Two Bridges, Saddle River at Ridgewood, and Rahway River near Springfield exceeded the TELs. All sites had two or more contaminants that exceeded the TELs, making potential synergistic effects of trace elements and organochlorine compounds an additional environmental concern.

\section{REFERENCES CITED}

Aguilar, Alex, 1984, Relationship of DDE/ $\Sigma$ DDT in Marine mammals to the Chronology of DDT Input into the Ecosystem: Canadian Journal of Fisheries and Aquatic Sciences, v. 41, p. 840-844.

Arbogast, Belinda, ed., 1996, Analytical methods manual for the mineral resource surveys program: U.S. Geological Survey Open-File Report 96-525, 248 p.

Breault, R.F., and Harris, S.L., 1997, Geographical distribution and potential for adverse biological effects of selected trace elements and organic compounds in streambed-sediment in the Connecticut, Housatonic, and Thames River Basins, 1992-94: U.S. Geological Survey WaterResources Investigations Report 97-4169, $24 \mathrm{p}$.

Brigham, M.E., Goldstein, R.M., and Tornes, L.H., 1997, Trace elements and organic chemicals in stream-bottom sediments and fish tissues, Red River of the North Basin, Minnesota, North Dakota, and South Dakota, 1992-95: U.S. Geological Survey Water Resources Investigations Report 97-4043, 32 p.
Canadian Council of Resource and Environment Ministers, 1992, Canadian Water-Quality Guidelines: Ottawa, Ontario, Ecosystems Sciences and Evaluations Directorate, $218 \mathrm{p}$.

Carter, L.F., 1997, Water-quality assessment of the Rio Grande Valley, Colorado, New Mexico, and Texas--Organic compounds and trace elements in bed sediment and fish tissues, 1992-93: U.S. Geological Survey Water-Resources Investigations Report 97-4002, 23 p.

Coles, J.F., 1996, Organochlorine compounds and trace elements in fish tissue and ancillary data for the Connecticut, Housatonic, and Thames River Basins Study Unit, 1992-94: U.S. Geological Survey Open-File Report 96-358, 26 p.

Coles, J.F., 1998, Organochlorine compounds in fish tissue from the connecticut, Housatonic, and Thames River Basins study unit, 1992-94: Water-Resources Investigations Report 98-4075, $22 \mathrm{p}$.

Crawford, J.K., and Luoma, S.N., 1993, Guidelines for studies of contaminants in biological tissues for the National WaterQuality Assessment Program:

U.S. Geological Survey Open- File Report 92-494, $69 \mathrm{p}$.

Deluca, M.J., Oden, J.H., Romanok, K.M., Riskin, M.L., 1999, Water-resources data for New Jersey-water year 1998, Volume 3. Water-quality data: U.S. Geological Survey Water-Data Report NJ-98-3, 450.

Durlin, R.R., and Schaffstall, W.P., 1995, Water-resources data for Pennsylvaniawater year 1994, Volume 2. Susquehanna and Potomac River Basins: U.S. Geological Survey Water-Data Report PA-94-2, 418 p. 
Durlin, R.R., and Schaffstall, W.P., 1996, Water-resources data for Pennsylvaniawater year 1995, Volume 2. Susquehanna and Potomac River Basins:

U.S. Geological Survey Water-Data Report PA-95-2, 518 p.

Ecosystem Conservation Directorate Evaluation and Interpretation Branch, 1995, Interim sediment quality guidelines: Ottawa, Ontario, Environment Canada, Soil and Sediment Quality Section, Guidelines Division (final unpublished draft), $52 \mathrm{p}$.

Environment Canada, 1997, Canadian tissue residue guidelines for DDT for the protection of wildlife consumers of aquatic biota: Hull, Quebec, Science Policy and Environmental Quality Branch, Guidelines and Standards Division (final unpublished draft), $85 \mathrm{p}$.

Fields, T.W., McNevin, T.F., and Harkov, R.A., 1992, A summary of selected soil constituents and contaminants at baseline locations in New Jersey: New Jersey Department of Environmental Protection, Division of Science and Research, $43 \mathrm{p}$.

Foreman, W.T., Connor, B.F., Furlong, E.T., Vaught, D.G., and Merten, L.M., 1995, Methods of analysis by the U.S. Geological Survey National Water Quality Laboratory--Determination of organochlorine pesticides and polychlorinated biphenyls in bottom sediment by dual capillary-column gas chromatography with electron-capture detection: U.S. Geological Survey OpenFile Report 95-140, 78 p.

Forstner, Ulrich, and Wittman, G.T.W., eds., 1983, Metal pollution in the aquatic environment ( $2 \mathrm{~d}$ ed): New York, SpringerVerlag, $486 \mathrm{p}$.
Harris, S.L., 1997, Inorganic and organic constituents and grain-size distribution in streambed sediment and ancillary data for the Connecticut, Housatonic, and Thames River Basins Study Unit, 1992-94: U.S. Geological Survey Open-File Report 96-397, $39 \mathrm{p}$.

Harte, John, Holdren, Cheryl, Schneider, Richard, and Shirley, Christine, 1991, Toxics A to $\mathrm{Z}$-- A guide to everyday pollution hazards: Los Angeles, Calif., University of California Press, $478 \mathrm{p}$.

Hoffman, G.L., 1996, Methods of analysis by the U.S. Geological Survey National Water Quality Laboratory-Preparation procedure for aquatic biological material determined for trace metals:

U.S. Geological Survey Open-File Report 96-362, 42 p.

Leiker, T.J., Madsen, J. E., Deacon, J.R., and Foreman, W.T., 1995, Methods of analysis by the U.S. Geological Survey National Water Quality Laboratory -Determination of chlorinated pesticides in aquatic tissue by capillary-column gas chromatography with electron-capture detection: U.S. Geological Survey OpenFile Report 94-710, 42 p.

Long, E.R., and Morgan, L.G., 1991, The potential for biological effects on sediment-sorbed contaminants tested in the National Status and Trends Program: U.S. National Oceanic and Atmospheric Administration, Technical Memo NOS/ OMA 52, $175 \mathrm{p}$.

Meador, M.R., Cuffney, T.F., and Gurtz, M.E., 1993, Methods for sampling fish communities as part of the National Water-Quality Assessment Program: U.S. Geological Survey Open-File Report 93-104, $40 \mathrm{p}$. 
Miller, P.A., Munkittrick, K.R., and Dixon, D.G., 1992, Relationship between concentrations of copper and zinc in water, sediment, benthic invertebrates, and tissues of white sucker (Catostomus commersoni) at metal-contaminated sites: Canadian Journal of Fisheries and Aquatic Sciences, v. 49, p. 978-984.

Nadakavukaren, Anne, 1995, Our global environment--A health perspective (4th ed): Prospect Heights, Ill., Waveland Press, $711 \mathrm{p}$.

National Academy of Sciences and National Academy of Engineering, 1972, Water quality criteria 1972: Washington, D.C., U.S. Environmental Protection Agency, $594 \mathrm{p}$.

National Oceanic and Atmospheric Administration, 1993, Point source methods document-the national coastal pollutant discharge inventory: Silver Spring, Md., Pollution Sources Characterization Branch, variously paginated.

New Jersey Department of Environmental Protection and Energy, 1993, Polychlorinated Biphenyls (PCBs), chlordane, and DDTs in selected fish and shellfish from New Jersey waters, 19881991--Results from New Jersey's Toxics in Biota Monitoring Program: New Jersey Department of Environmental Protection and Energy, Division of Science and Research, $95 \mathrm{p}$.

New Jersey Department of Environmental Protection, 1995, New Jersey State Water Quality Inventory Report, 1994: New Jersey Department of Environmental Protection, Office of Environmental Planning, p. III-1-III-48.
New Jersey Department of Environmental Protection, 1996, GIS Resource Data, CD-ROM series 1, v. 1-3: New Jersey Department of Environmental Protection, Bureau of Geographic Information and Analysis, Office of Information Resources Management.

New Jersey Department of Environmental Protection, 1998, New Jersey Superfund sites on the National Priorities List: New Jersey Department of Environmental Protection, Site Remediation Program, $4 \mathrm{p}$.

New York State Department of Environmental Conservation, 1985, Environmental impact statement for proposed policy on contaminants in fish: Albany, N.Y., New York State Department of Environmental Conservation, Division of Fish and Wildlife, FW P-261, 77 p.

Nriagu, J.O., and Pacyna, J.M., 1988, Quantitative assessment of worldwide contamination of air, water, and soils by trace metals: Nature, v. 333, p. 134-139.

O’Brien, A.K., 1997, Presence and distribution of trace elements in New Jersey streambed sediments: Journal of the American Water Resources Association, v. 33, no. 2, p. $387-403$.

Ondov, J.M., Zoller, W.H., and Gorden, G.E., 1982, Trace element emissions on aerosols from motor vehicles: Environmental Science and Technology, v. 16 , no. 6 , p. 318-328.

Rice, K.C., 1999, Trace-element concentrations in streambed sediment across the conterminous United States: Environmental Science and Technology, v. 33 , no. 15 , p. $2499-2504$. 
Robinson, K.W., Price, C.V., and Smith, R.A., 1995, Development of computerized data base of permitted wastewater discharges in New Jersey: U.S. Geological Survey Open-File Report 95-152, 14 p.

Saiki, M.K., and May, T.W., 1988, Trace elements residues in bluegills and common carp from the Lower San Joaquin River, California, and its tributaries: The Science of the Total Environment, v. 74, p. 199-217.

Schmitt, C.J., Ludke, J.L., and Walsh, E.F., 1981, Organochlorine residues in fishNational Pesticide Monitoring Program, 1970-74: Pesticide Monitoring Journal, v. 14 , no. 4 , p. $136-206$.

Schueler, T.R., 1994, The importance of imperviousness: Watershed Protection Techniques, v. 1, no. 3, p. 100-111.

Shelton, L.R., 1996, Guidelines for collecting and processing samples of stream bed sediment for analysis of trace elements and organic contaminants for the National Water-Quality Assessment Program: U.S. Geological Survey Open-File Report 94-456, $21 \mathrm{p}$.

Smith, J.A., Witkowski, P.J., and Fusillo, T.V., 1988, Manmade organic compounds in the surface waters of the United States-A review of current understanding: U.S. Geological Survey Circular 1007, $92 \mathrm{p}$.

Stackelberg, P.E., 1997, Presence and distribution of chlorinated organic compounds in streambed sediments, New Jersey: Journal of the American Water Resources Association, v. 33, no. 2, p. 271-284.
Stankowski, Stephen J., 1974, Magnitude and frequency of floods in New Jersey with effects of urbanization: U.S. Geological Survey Special Report 38, 46 p.

U.S. Bureau of the Census, 1991, Census of populations and housing, 1990: Public Law 94-171 Data for New Jersey: Washington, D.C., U.S. Bureau of the Census, unpaginated.

U.S. Environmental Protection Agency, 1979, Water-related environmental fate of 129 priority pollutants, Volume 1: Washington, D.C., Office of Water, EPA-440/4-79-029a, $473 \mathrm{p}$.

U.S. Environmental Protection Agency, 1997, Guidance for assessing chemical contaminant data for use in fish advisories--Volume 2 risk assessment and fish consumption limits ( $2 \mathrm{~d}$ ed.): Washington, D.C., Office of Water, EPA 823-B-97-009, chap. 5, 146 p.

Velz, C. J., 1984, Applied stream sanitation ( $2 \mathrm{~d}$ ed): New York, John Wiley \& Sons, $800 \mathrm{p}$.

Ware, G.W., 1994, The pesticide book (4th ed.): Fresno, Calif., Thomson Publications, $386 \mathrm{p}$.

Winger, P.V., Schultz, D.P., and Johnson, W.W., 1990, Environmental contaminant concentrations in biota from the Lower Savannah River, Georgia and South Carolina: Archives of Environmental Contamination and Toxicology, v. 19, p. 101-117.

Winter, Mark, 1998, WebElements: UK, University of Sheffield, Accessed on the World Wide Web at URL http://www.webelements.com. 
Printed on recycled paper 